Nat. Hazards Earth Syst. Sci., 20, 673-694, 2020

https://doi.org/10.5194/nhess-20-673-2020

(C) Author(s) 2020. This work is distributed under the Creative Commons Attribution 4.0 License.

\title{
High-accuracy coastal flood mapping for Norway using lidar data
}

\author{
Kristian Breili $^{1,2}$, Matthew James Ross Simpson ${ }^{1}$, Erlend Klokkervold ${ }^{3}$, and Oda Roaldsdotter Ravndal ${ }^{4}$ \\ ${ }^{1}$ Geodetic Institute, Norwegian Mapping Authority, 3507 Hønefoss, Norway \\ ${ }^{2}$ Faculty of Science and Technology, Norwegian University of Life Sciences, 1432 Ås, Norway \\ ${ }^{3}$ Geographic Information System Development, Norwegian Mapping Authority, 3507 Hønefoss, Norway \\ ${ }^{4}$ Hydrographic Service, Norwegian Mapping Authority, 4021 Stavanger, Norway
}

Correspondence: Kristian Breili (kristian.breili@kartverket.no)

Received: 4 July 2019 - Discussion started: 12 August 2019

Revised: 23 December 2019 - Accepted: 20 January 2020 - Published: 27 February 2020

\begin{abstract}
Using new high-accuracy light detection and ranging (lidar) elevation data we generate coastal flooding maps for Norway. Thus far, we have mapped $\sim 80 \%$ of the coast, for which we currently have data of sufficient accuracy to perform our analysis. Although Norway is generally at low risk from sea level rise largely owing to its steep topography and land uplift due to glacial isostatic adjustment, the maps presented here show that, on local scales, many parts of the coast are potentially vulnerable to flooding. There is a considerable amount of infrastructure at risk along the relatively long and complicated coastline. Nationwide we identify a total area of $400 \mathrm{~km}^{2}, 105000$ buildings, and $510 \mathrm{~km}$ of roads that are at risk of flooding from a 200-year storm surge event at present. These numbers will increase to $610 \mathrm{~km}^{2}, 137000$, and $1340 \mathrm{~km}$ with projected sea level rise to 2090 (95th percentile of RCP8.5 as recommended in planning). We find that some of our results are likely biased high owing to erroneous mapping (at least for lower water levels close to the tidal datum which delineates the coastline). A comparison of control points from different terrain types indicates that the elevation model has a root-mean-square error of $0.26 \mathrm{~m}$ and is the largest source of uncertainty in our mapping method. The coastal flooding maps and associated statistics are freely available, and alongside the development of coastal climate services, will help communicate the risks of sea level rise and storm surge to stakeholders. This will in turn aid coastal management and climate adaptation work in Norway.
\end{abstract}

\section{Introduction}

Higher sea levels driven by anthropogenic climate change present a large challenge for many coastal communities. There are numerous negative consequences of sea level rise, i.e., flooding, loss of life and land, damage and loss of buildings and infrastructure, increased erosion, saltwater intrusion, changing ecosystems, and reduced biodiversity (see, e.g., Nicholls, 2010; Nicholls and Cazenave, 2010). The consequences of increasing sea level are large because coastal zones are densely populated areas, have a large population growth, and are economically important.

Compared to many other coastal nations, Norway is at relatively low physical vulnerability to accelerating sea level rise (Aunan and Romstad, 2008). Norway has a very rugged coast with fjords, inlets, and many thousands of islands. The coastline is relatively long, being around $103000 \mathrm{~km}$ in length (Kartverket, 2019a), and is largely characterized by steep topography and an exposed bedrock that is resistant to erosion. An important component of sea level change for Norway is vertical land motion (VLM) due to glacial isostatic adjustment. Regional differences in VLM essentially explain differences in observed sea level changes along the coast. Observations from Norway's tide gauge network show that relative sea level fell over the recent period 1984-2014 around Oslo and in the middle of Norway, where VLM is largest. Whereas other parts of the coast experienced a limited sea level rise (Breili et al., 2017). Sea level is projected to increase along the entire coastline over the 21 st century, albeit below the global mean change (Simpson et al., 2015, 2017). This means Norway will have to adapt to rising sea levels. 
Despite these generally favorable conditions, the long and complicated nature of the coast means there are many areas, often on local scales, which are potentially vulnerable to sea level rise. Aunan and Romstad (2008) identified three lowlying types of coastline which are at risk: (1) the strandflat, which is a flattish erosional surface that fringes much of Norway; (2) glaciofluvial deltas, which are often situated at the head of fjords; and (3) the soft moraine coast in the southwest of the country. Furthermore, many of Norway's cities and population centers are located on the coast and have undertaken large coastal developments in recent years. There are also important industries (oil, fishing, aquaculture, tourism), cultural buildings, extensive infrastructure, and many homes and cabins in the coastal zone that are potentially at risk. Cultural monuments that are close to the sea include Bryggen (the old harbor in Bergen) and the Vega archipelago, which are both on the UNESCO (United Nations Educational, Scientific, and Cultural Organization) World Heritage List (UNESCO, 2019).

Coastal flooding due to storm surges have caused considerable damage along the Norwegian coast in the past. Generally speaking, damage is limited to areas very close to the coastline owing to the steep topography. And the consequences of these extreme events have been relatively minor when compared to other parts of the world (i.e., few severe consequences like loss of life and property). There is no dataset available which allows for a complete assessment of the damage costs from these past storm surge events. However, a sense of the costs can be understood from insurance compensation data, which give costs from building damage but not from, e.g., roads or agriculture. Insurance data from 1980 to 2018 show a total of EUR 140 million has been paid out owing to storm surge damage (data from Norwegian Natural Perils Pool and Finance Norway, adjusted for inflation). The years 1987 and 2011 stand out, with annual insurance compensation of EUR 27 million and EUR 47 million due to storm surges, respectively. Damages in 2011 were essentially caused by two storm surge events, the storms Dagmar (24 December 2011) and Berit (26 November 2011). Given that sea levels are now rising along parts of the Norwegian coast, how might these numbers change in the future?

The potential consequences of future flooding can be assessed by combining sea level scenarios with other types of geospatial data like elevation data and registers over buildings, roads, and critical infrastructure. In addition, a detailed impact assessment requires an analysis of the possibilities for adaptation, assessment of value, usage, and the expected life span of objects at risk. To our knowledge, no national socioeconomic study exists that is dedicated to sea level rise and extreme sea levels for Norway. However, Almås and Hygen (2012) looked at one aspect of the problem by examining the potential impact of sea level rise on Norwegian buildings. They identify approximately 110000 buildings with heights below $1 \mathrm{~m}$ measured in the former Norwegian height system NN1954. More than $40 \%$ of the buildings are antici- pated as being of significant economic value, i.e., they are homes or cabins, industry, storage, hotels, restaurants, office buildings, shops, etc. Their findings indicate that the western coast of Norway is the region most at risk from sea level rise. In total, the costs of constructional measures for adapting the existing buildings for higher sea level are estimated to EUR 725 million. Norway is also included as part of the European study by Vousdoukas et al. (2018a). They conclude that Norway is one of the countries that shows the highest absolute increase in expected annual damage and expected annual number of people exposed to coastal flooding towards the end of the century. They find that by 2100 , annual damages will increase to between $1.7 \%$ and $5.9 \%$ of GDP. The main driver of this increase is climate change, with changes in economic growth patterns as a secondary effect. This result suggests that the costs of sea level rise for Norway could be very significant.

In this study, we describe the methods and results from the first generation of nationwide inundation maps for Norway. For the first time, sea level projections are combined with new national high-accuracy light detection and ranging (lidar) elevation data, tidal and storm surge height information, and geospatial data in order to map coastal flooding in Norway. The main difference between our approach and past analyses is that here we use new high-accuracy lidar elevation data. The resulting maps have been made available to end users as part of the coastal climate service "Se havnivå $\mathrm{i}$ kart" (in English: "View sea level rise in maps") (see Kartverket, 2019c) created by the Norwegian Mapping Authority. The service provides a web tool for visualizing the potential effects of coastal flooding and presents associated numbers over exposed objects.

The demand for sea level projections in coastal climate services is driven by three main end user needs (Titus and Narayanan, 1995; Le Cozannet et al., 2017):

1. Identifying research needs,

2. Examining the consequences and benefits of sea level projections for different greenhouse gas emission scenarios (mitigation),

3. Understanding and communicating information that can help society adapt to present and future sea level rise (adaptation).

Se havnivå i kart is primarily focused on providing information that can be used in climate adaptation work. The service provides inundation maps for both present sea level and future sea level in 2090. These sea level heights can be combined with different return heights for storm surges that correspond to safety classes given in the current building acts and regulations for Norway (TEK, 2019). In addition, there are inundation maps indicating exposed objects and areas at $1 \mathrm{~m}$ height intervals set between 1 and $5 \mathrm{~m}$ above the present mean high water (MHW). The service has been tailored to 
assist Norway's coastal municipalities with emergency preparedness, long-term planning decisions, and communicating the risks associated with storm surge and sea level rise to the public and other stakeholders.

In the following we describe the methods and data used for creating the inundation maps and associated numbers over exposed objects. We show results for a variety of storm surge heights and water levels. Furthermore, we show how these results vary regionally for different categories of land use, buildings, and roads. The discussion examines the accuracy and reliability of the maps and addresses some issues of how to interpret the results.

\section{Methods and data}

Our inundation maps and associated statistics are generated by combining sea level projections and storm surge return heights with a digital elevation model (DEM) and map databases of buildings, land coverage, and roads. These data are referenced to different vertical datums. Thus, to combine these data in a common vertical reference system requires knowledge of the different vertical datums and how to transform between them. For example, to visualize the height of MHW in the national height system (NN2000) requires knowledge of these two vertical datums and also the relationship between them. Strauss et al. (2012) stress that topographic vulnerability must be assessed with respect to local water levels, and not, e.g., a nationwide definition of elevation zero. In Se havnivå i kart, varying tidal heights along the Norwegian coast are considered by using water levels above MHW and storm surge heights that include the effect of the astronomical tides. The resulting water levels can then be transformed to the present national vertical reference system of Norway, NN2000, by exploiting MHW's known height in NN2000.

\subsection{Sea level projections and storm surge return heights}

Official regional sea level projections for Norway are based on science from the Fifth Assessment Report from the Intergovernmental Panel on Climate Change (IPCC AR5) (Taylor et al., 2012; Church et al., 2013). The projections show increasing sea levels for the entire coastline over the 21 st century, albeit below the global mean change (Simpson et al., $2015,2017)$. VLM due to glacial isostatic adjustment is an important component of sea level change for Norway and observations indicate it varies between 1 and $5 \mathrm{~mm} \mathrm{yr}^{-1}$ along the coast (Kierulf et al., 2014; Vestøl, 2006). VLM therefore acts to mitigate sea level rise in Norway and essentially explains why rates of sea level change vary from location to location. The VLM field used in the projections is based upon permanent GPS observations and repeated leveling (see Simpson et al., 2015). The presence of small-scale anoma- lies, e.g., urban subsidence or neotectonics (Olesen et al., 2013), may cause VLM to deviate significantly from this field at the local level.

Guidelines from the Norwegian Directorate for Civil Protection (DSB) recommend that the upper 95th percentile of the spread of the projections for RCP8.5 be used in coastal planning. The upper 95th percentile corresponds to the top of the likely range in IPCC terminology. As projected sea level rise varies considerably along the coast, the projections are given for each coastal municipality ( 273 in total). Therefore, depending on the location, the recommended sea level increase for use in planning varies between 0.40 and $0.82 \mathrm{~m}$ (Simpson et al., 2015); see Fig. 1. These numbers are rounded to the nearest $0.10 \mathrm{~m}$ before use in planning.

For RCP8.5, a high-emission scenario, the projected likely global temperature increase is $3-5^{\circ} \mathrm{C}$ for the period $2081-$ 2100 relative to $1986-2005$ (IPCC, 2013). With a view to sea level rise, the likely range of the model output is considered to cover $66 \%-100 \%$ of the total possible future outcomes (Church et al., 2013). Consequently, higher sea level rise by 2100 cannot be ruled out. There is especially large uncertainty associated with the projected contribution from the large ice sheets in Antarctica and Greenland. Observations indicate that the ice sheet contribution has nearly doubled from the period 2002-2006 to 2012-2016 (Bamber et al., 2018). DeConto and Pollard (2016) find that Antarctica has the potential to contribute more than a meter of sea level rise by 2100 if emissions continue unabated, but this is only one study and the physical processes required remain controversial (see, e.g., Edwards et al., 2019). We also expect further sea level rise after 2100. Clark et al. (2016), for example, conclude that current emissions levels have committed Earth to a further global mean sea level (MSL) rise of 1.2 to $2.2 \mathrm{~m}$ above the present sea level. While Strauss et al. (2015) find that unabated carbon emissions up to the year 2100 would lead to an eventual global sea level rise of 4.3 to $9.9 \mathrm{~m}$. To explore sea level scenarios above the likely range as recommended for coastal planning and for scenarios beyond 2100 , we therefore also present numbers for water levels 1, 2, 3, 4, and $5 \mathrm{~m}$ above the present-day MHW. These levels can help stakeholders better understand the sensitivity and vulnerability of the coast to different future scenarios.

Storm surge return heights are calculated from tide gauge observations, i.e., we assume no change in extreme sea levels with future climate change. Note that calculated return heights do not include the potential effects of wave setup and runup, and the effects of river flooding are not explicitly included in the estimates of present and future extreme sea levels. The storm surge return heights used here correspond to safety classes in the current building acts and regulations for Norway (TEK, 2019), i.e., water levels that on average arise once within a period of 20,200, and 1000 years. The return heights were calculated by analyzing observations from 23 permanent and several hundred temporal tide gauges along the Norwegian coast. The Average Conditional Ex- 


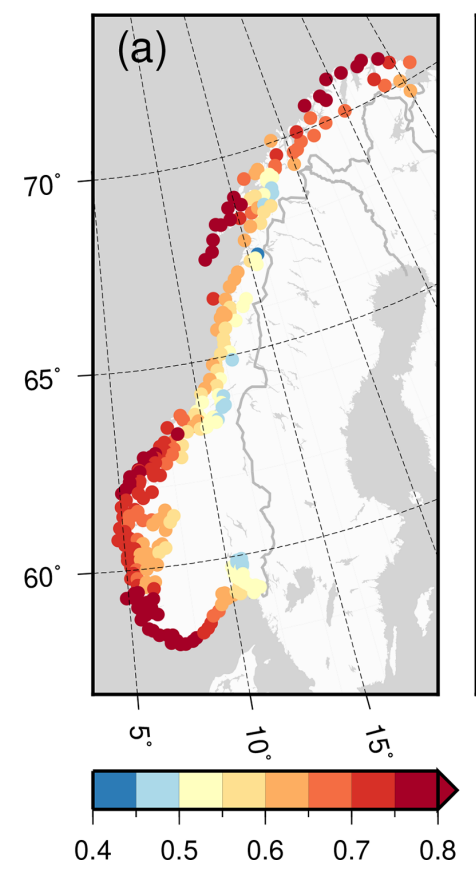

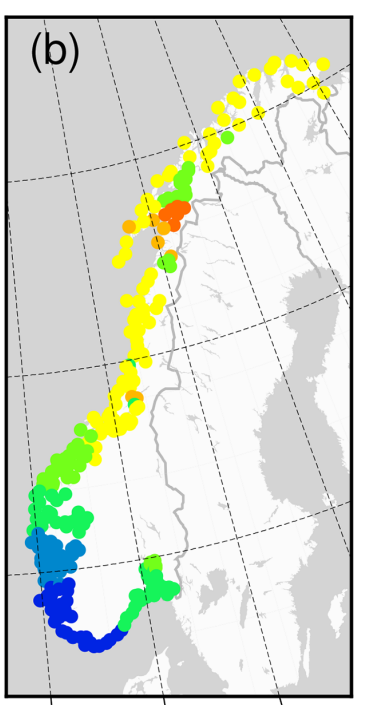

G. $\overrightarrow{0}$

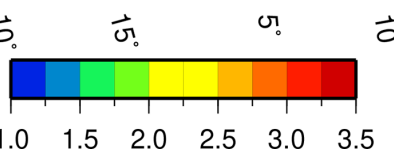

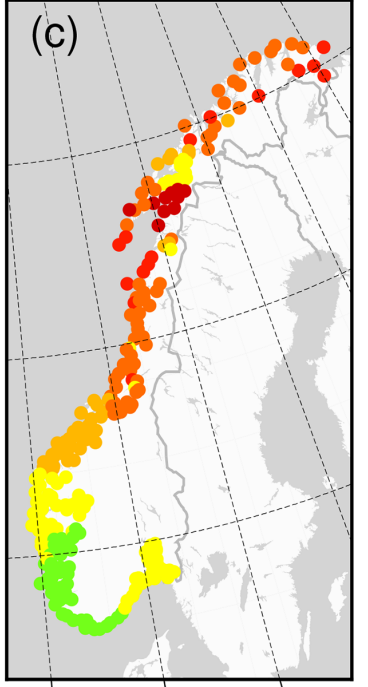

के ज.

Figure 1. Projected relative sea level (RSL) change for the period 2081-2100 relative to 1986-2005 (a), 200-year storm surge return height above MHW (b), and the sum of these two (c). For all figures the values are given in meters.

ceedance Rate (ACER) statistical method (Næss and Gaidai, 2009; Skjong et al., 2013) was used, which is a type of model that allows return heights for periods longer than the tide gauge records to be estimated.

For each coastal municipality, the return heights have been calculated for one to three locations. To be able to predict return heights at a point away from a permanent tide gauge, analysis of records from temporal tide gauges and oceanographic knowledge have been used to divide the Norwegian coast into zones with similar tidal properties. For these zones, adjusted time series of water level can be created by first calculating the astronomical tide according to the tidal zone. Then the meteorological effect as observed by the closest permanent tide gauge is added and the ACER method is applied to the resulting time series. Unfortunately, there are areas along the Norwegian coast where the tidal zones cannot be determined, i.e., inside fjords, bays, and where narrow straits change the tidal properties over short distances. Along the southwestern coast, there is a lack of meteorological observations, and the tidal properties are complex due to an amphidromic point off the coast. The adjusted time series for these areas are not sufficiently accurate for tidal predictions but can still be used to calculate return heights for storm surges.

We present maps and associated numbers visualizing both present storm surge return heights and return heights combined with projected relative sea level rise. The numbers for present storm surge return heights represent today's risk and are useful for disaster preparedness, while storm surge heights for 2090 are important for planning. Finally, in order to illustrate the potential effects of a storm surge with a scenario of sea level rise above the IPCC AR5 based projections, we include numbers for a 1000-year storm surge combined with a sea level rise $1 \mathrm{~m}$ above that recommended for use in planning, which may be relevant if rapid Antarctic ice mass loss becomes reality.

\subsection{The digital elevation model}

Having a DEM with high vertical accuracy and high horizontal resolution is an important prerequisite for producing reliable inundation maps (Gesch, 2018). Gesch (2009) demonstrates that high-accuracy elevation data with high spatial resolution from lidar provide a more accurate delineation of inundation zones than other types of elevation data. In developed areas, where small changes in the delineation of the sea may involve many objects, this can be critical.

We have used the national detailed height model of Norway (Kartverket, 2014) to estimate topographic vulnerability due to increasing sea level (available to download at https: //hoydedata.no/LaserInnsyn/, last access: 24 February 2020). The DEM is primarily based on airborne topographic mapping by lidar and photogrammetric matching of aerial photos of resolution $0.25 \mathrm{~m} \times 0.25 \mathrm{~m}$ in mountain areas. It has a spatial resolution of $1 \mathrm{~m} \times 1 \mathrm{~m}$ and is calculated from a point cloud of at least two points per square meter in the areas mapped by lidar. Two methods are applied to interpolate the lidar data to a regular DEM. As a first attempt, naturalneighbor interpolation (Sibson, 1981) was used. If this failed, 
empty spaces were binned with an average value. The vertical accuracy of the lidar data has a production goal rootmean-square error (RMSE) of $0.1 \mathrm{~m}$ for well-defined solid areas (Kartverket, 2014). The DEM was transformed from ellipsoidal heights to NN2000 by using the height reference surface HREF (Solheim, 2000).

Presently, about $80 \%$ of Norway is covered by the DEM, and the entire country is expected to be mapped by 2023 . We assume no geomorphologic changes (e.g., erosion) or manmade landscape interventions take place over time, i.e., the same elevation data are used to map sea level rise and storm surge today and for 2090.

In order to identify flooded zones, we have followed a "bathtub" approach similar to the one outlined in, e.g., Gesch (2009), Rowley et al. (2007), and Poulter and Halpin (2008). The bathtub approach is favored for several reasons. Firstly, mapping results from this approach are consistent with how current guidelines on coastal planning are applied in Norway. Secondly, the approach is straightforward, computationally inexpensive, and has been widely used in large-scale coastal flooding analyses. However, there are known limitations of the bathtub method. For example, the responses of hydrodynamics, morphology, and ecology as sea level rises are not accounted for (see Passeri et al., 2015 for a review). Some of these effects could be important on local scales along the Norwegian coast.

A particular cell in the DEM must fulfill two criteria in order to be classified as flooded. First, it must have a height below the given sea level rise scenario or storm surge return height and, secondly, it must be in hydrological connection to the sea. The latter is important to eliminate low-lying areas that are protected by embankments and barriers like elevated roadbeds with heights above the sea level scenario. The spatial extension of the sea for a given inundation level is then delineated by polygons that surround the cells in the DEM classified as flooded. Note that these polygons are not isolines with constant heights. The height of, e.g., $\mathrm{MHW}+1 \mathrm{~m}$ in NN2000 varies along the coast.

\subsection{Buildings, land cover, and road datasets}

The inundation maps generated from the DEM are the basic product of Se havnivå i kart. Objects affected by increasing sea level can be identified by overlaying the polygons representing the flooded areas with datasets of buildings, roads, and land coverage. This approach makes it possible to map the consequences of coastal flooding for all types of geospatial data and makes the analysis more flexible than an approach where the object's height determines whether the object is exposed.

For roads and land coverage, we have used datasets that are customized for the scale range $1: 25000$ to $1: 100000$. These datasets cover mainland Norway and have a horizontal accuracy of 2 to $50 \mathrm{~m}$. The data are cartographically edited for presentation on a scale of $1: 50000$ and are named N50.
To map affected buildings, the building register that is part of the Norwegian database for basic maps was used (Geonorge, 2019; Kartverket, 2019b). The datasets have a horizontal accuracy between 0.2 and $2 \mathrm{~m}$, depending on object type, location, and method used for surveying the objects. Affected buildings are calculated by counting the number of objects inside or intersecting the polygons delineating the regions of inundation. For roads and areas, the objects are clipped, i.e., only the parts of the object inside the polygons are included in the statistics. For the roads, the length of the centerlines are summarized.

Owing to Norway's steep topography, the horizontal location is critical for determining whether an object is exposed or not. A weakness of the methodology outlined above is that objects located very close to the coast or directly above the sea surface may be erroneously mapped as exposed and bias the statistics. Unfortunately, basic maps of Norway do not include attributes that allow these buildings to be sieved out and removed from the statistics. As a consequence, the number of objects affected by coastal flooding for present MHW appear to be biased high. Here we consider MHW as the water level at which objects are permanently inundated by coastal flooding. Therefore, for present MHW the numbers of affected objects should be close to zero. However, we find an area of $152 \mathrm{~km}^{2}, 40072$ buildings, and $180 \mathrm{~km}$ of roads mapped as permanently flooded for present MHW.

The large area identified as flooded for present MHW indicates that there is a misfit between the polygons that define the flooded area and the land tiles used in Norwegian maps. In principle, the polygon and the coastline should match, but there are misfits due to different methods of mapping (lidar vs. photogrammetric analysis of aerial photos) and inaccuracies in the methods and data used in the analysis. Inspection of detailed maps and aerial photos indicates that many of the buildings erroneously mapped as flooded for present MHW are small boat houses situated very close to the coast or buildings on piers or pillars above the water surface; see Fig. 2. Roads erroneously mapped as flooded for present MHW include road sections on bridges and in underwater tunnels.

The numbers of affected objects for the storm surge return heights (e.g., 200-year storm surge height for 2090) are considerably higher than those for present MHW. To some extent, these numbers will also be in error owing to the present MHW bias. In order to reduce the effect of the MHW bias, we subtract the numbers calculated for present MHW for areas and roads where available. This implies that the size of affected areas is calculated between surfaces mapped with consistent methods. For roads it is unlikely that segments on bridges and in underwater tunnels will be affected, even for higher storm surge return heights.

We cannot, however, simply subtract the numbers calculated for present $\mathrm{MHW}$ from the numbers for higher water levels for buildings because an unknown number of these buildings will truly be affected by higher levels of flooding. We suggest that the numbers of buildings erroneously 


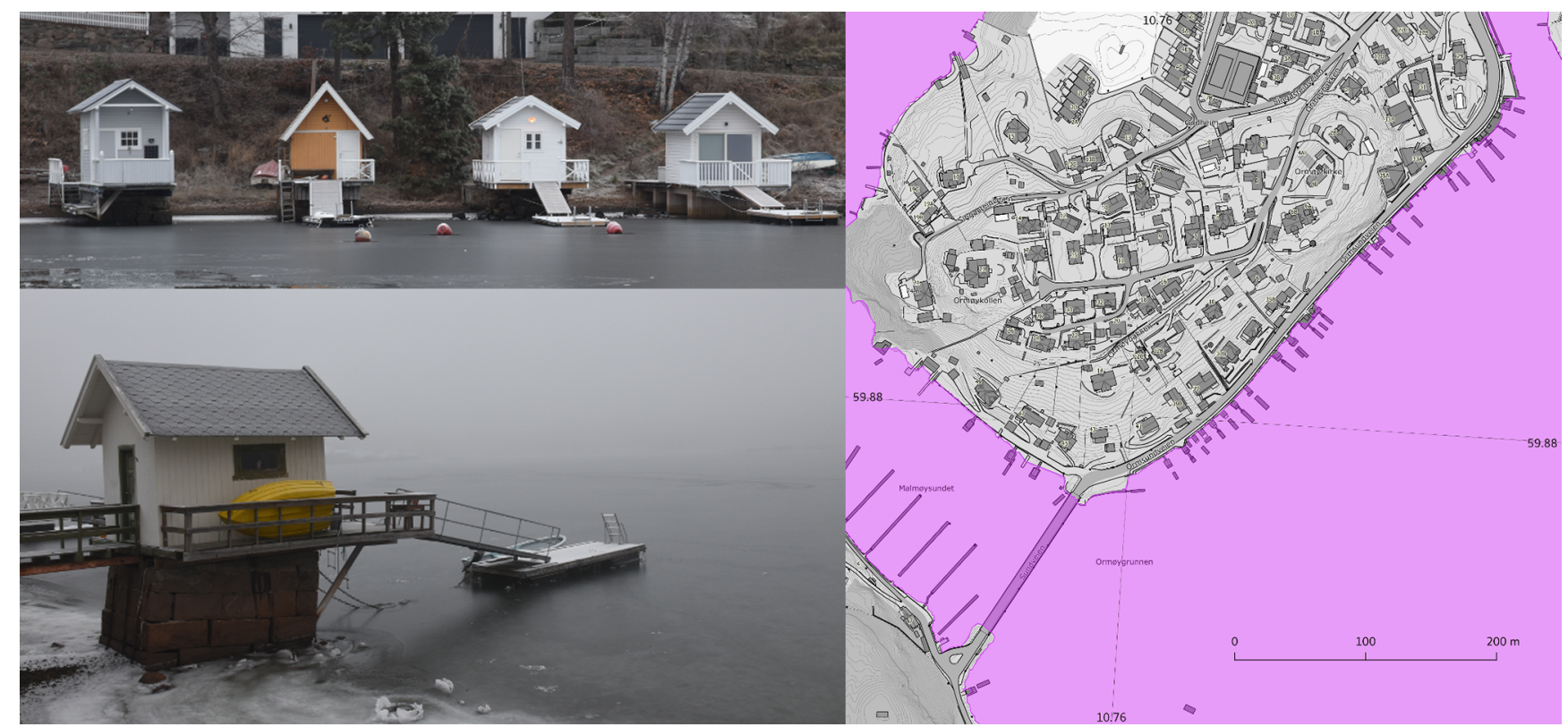

Figure 2. Buildings on piers or pillars above the water surface, like here at Ormøya close to Oslo, are erroneously mapped as flooded for present MHW (violet). Photo: Kristian Breili. Map data shown are provided by Geonorge and Norway Digital consortium and subject to the Norwegian License for Open Government Data (NLOD) 2.0 and Creative Commons BY 4.0 (CC BY 4.0).

mapped as affected will decrease for higher water levels. The numbers calculated for present MHW for buildings form a basis of estimates that other water levels can be compared to. They can also be considered a measure of the precision of the current methods and data used in our analysis. Note that because the coastal climate service Se havnivå i kart presents numbers including the MHW bias, the numbers for affected areas and roads given in Tables 2 and 4 will differ from those of Se havnivå i kart. Furthermore, the maps and numbers presented in Se havnivå i kart will be regularly updated as new knowledge and data (e.g., new elevation data, better understanding of vertical datums, error corrections) become available.

\section{Results}

Inundation maps and associated statistics are presently available for approximately $80 \%$ of the Norwegian coast; see Fig. 3. The maps and statistics cover the most densely populated areas and the larger coastal cities of Norway. We consider the inundation maps as the prime result of our analysis, and we first present examples of maps for geographically different areas of Norway. We go on to present national and regional statistics for objects at risk from coastal flooding derived from the maps.

\subsection{Examples of inundation maps of Norway}

Figure 4-7 show examples of inundation maps from Smøla, Lærdalsøyri, Randaberg, and Bergen (see Fig. 3 for loca- tions). These four locations represent the three types of coastlines (strandflat, glaciofluvial deltas, and soft moraine coast) understood to be at particular risk from sea level rise ( $\mathrm{Au}-$ nan and Romstad, 2008) and a large coastal city (Bergen). Together, they provide examples of how different communities in Norway can be affected by coastal flooding. Four water levels are illustrated in the figures: MHW and the 200year storm surge level, which are mapped both for today and for 2090 .

The municipality of Smøla is located on the strandflat in the middle of Norway and consists of one larger island surrounded by more than 3000 smaller islands. The strandflat is a shallow sea area with low-lying land areas found typically at the mouth of fjords and along the coast between fjords. The inundation maps from Smøla (see Fig. 4) indicate that sea level rise combined with storm surge will affect low-lying coastal areas as well as piers and buildings located close to the sea. Some roads that fringe the largest island and also those which connect islands in the municipality will be flooded. The fishing village of Veiholmen (see upper part of Fig. 4), located near to the northernmost part of Smøla and with a population of $\sim 200$, appears to be at particularly high risk with many buildings adversely affected. The maps also indicate that higher sea levels may cause saline ocean water to flow into rivers and creeks, with potential effects on local ecosystems. Smøla is the municipality in Norway with the second-largest land area affected by a 200-year storm surge, both at present (1.29 m above MHW) and for 2090 (2.03 m above MHW); see Figs. 12 and 13. Taking into account the municipalities total area, Smøla is the tenth and ninth most 


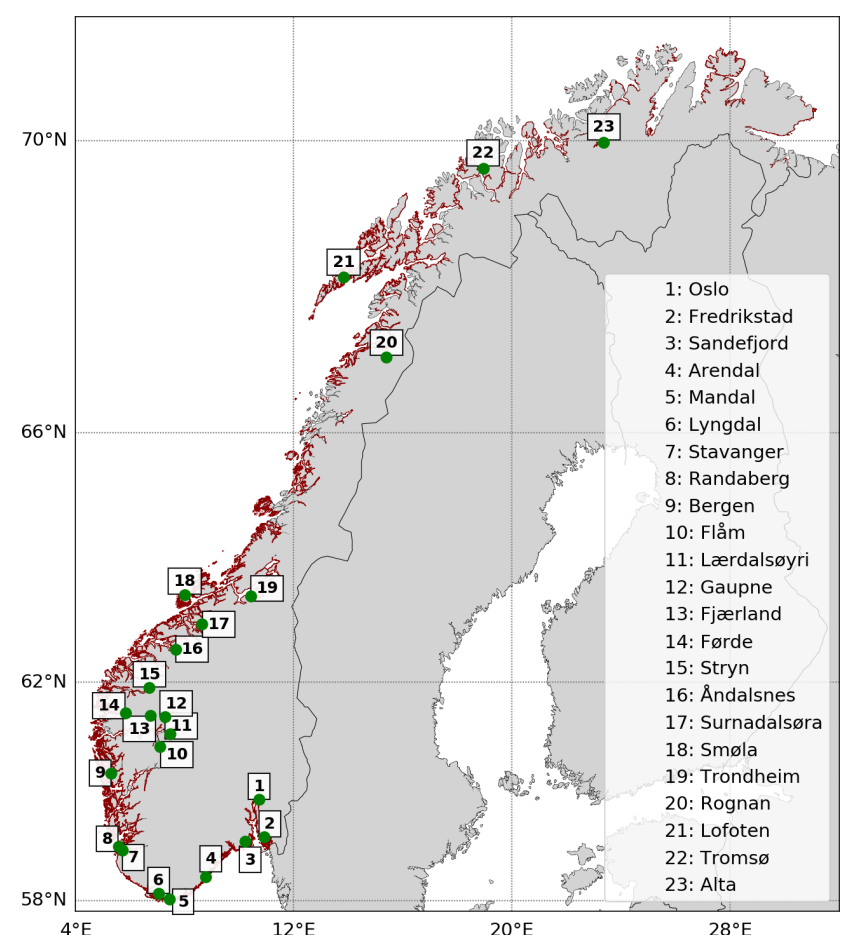

Figure 3. Red lines indicate areas covered by the inundation maps in December 2018. Information for all water levels is not available for all mapped zones due to a lack of knowledge of ocean tides for parts of the coast. In these zones, only the storm surge return heights can be calculated because they are not referenced to MHW. The green markers indicate locations discussed in the text.

affected municipality by a 200 -year storm at present and for 2090, respectively.

Figure 5 illustrates the potential effect of coastal flooding in Lærdalsøyri, a small village (population $~ 1100$ ) located on a glaciofluvial delta (see photo in Fig. 5). Many glaciofluvial deltas are found at the head of fjords in Norway. These deltas are typically flat and low-lying, densely populated, and attractive for industry and businesses. As the deltas are often surrounded by steep mountains, areas of development and agriculture are confined to the relatively flat river valley floors. In Lærdalsøyri, the combined effect of sea level rise and a 200 -year storm surge $(1.00 \mathrm{~m}$ above present MHW and $1.58 \mathrm{~m}$ above MHW for 2090) will cause flooding in the center of the village and surrounding areas. Buildings of historic interest, government offices, industry, businesses, and some residential areas are potentially at risk. Although levees that have been built to protect the village from river flooding appear to help restrict flooding from storm surge in some areas. We find other towns and villages located on glaciofluvial deltas show similar patterns of flooding, e.g., Lyngdal, Flåm, Fjærland, Gaupne, Stryn, Åndalsnes, Førde, Surnadalsøra, Rognan, and Alta.

While the strandflat consists of bedrock resistant to erosion, the southwest of Norway is characterized by soft

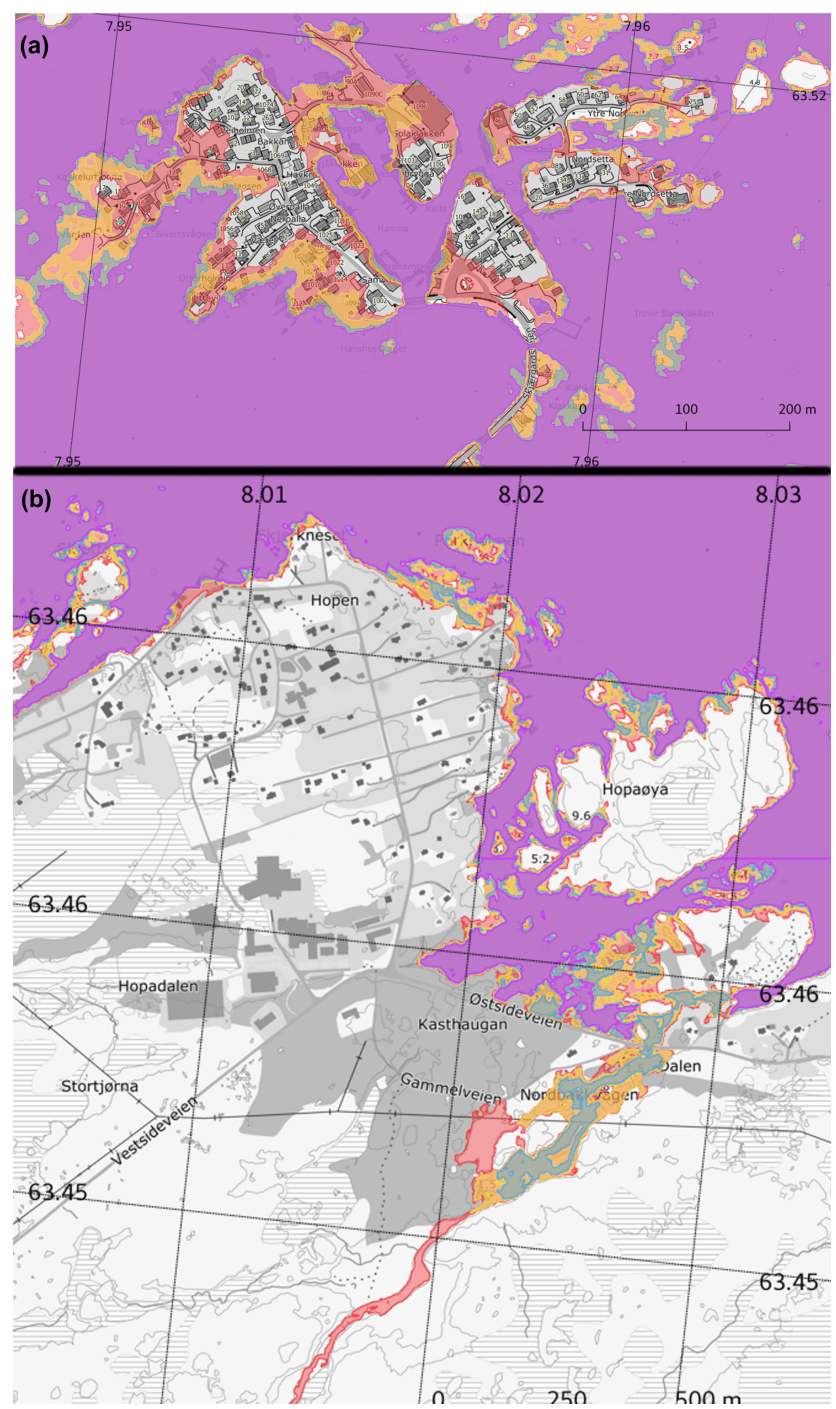

Figure 4. Stack of inundation maps covering the northern part of the island Smøla (a) and the fishing village of Veiholmen (b), located on the strandflat in the middle of Norway. Violet: present MHW. Green: MHW for 2090 (0.74 $\mathrm{m}$ above present MHW). Orange: present 200-year storm surge (1.29 m above present MHW). Red: 200-year storm surge for 2090 (2.03 m above present MHW). Map data shown are provided by Geonorge and Norway Digital consortium and subject to the Norwegian License for Open Government Data (NLOD) 2.0 and Creative Commons BY 4.0 (CC BY 4.0).

sediments, sandy shores, and sand dunes. These areas are sparsely populated but provide good opportunities for crop and livestock production. In general, the height of MHW is not known along the southwestern coast of Norway, except around Randaberg illustrated in Fig. 6. Despite the region's flat and low-lying terrain, the inundation maps indicate only small areas affected by coastal flooding. We find similar results along the entire southwestern coast, so these areas are at low risk. However, as the shoreline largely consists of sand and soft sediments, increased erosion due to sea level rise 


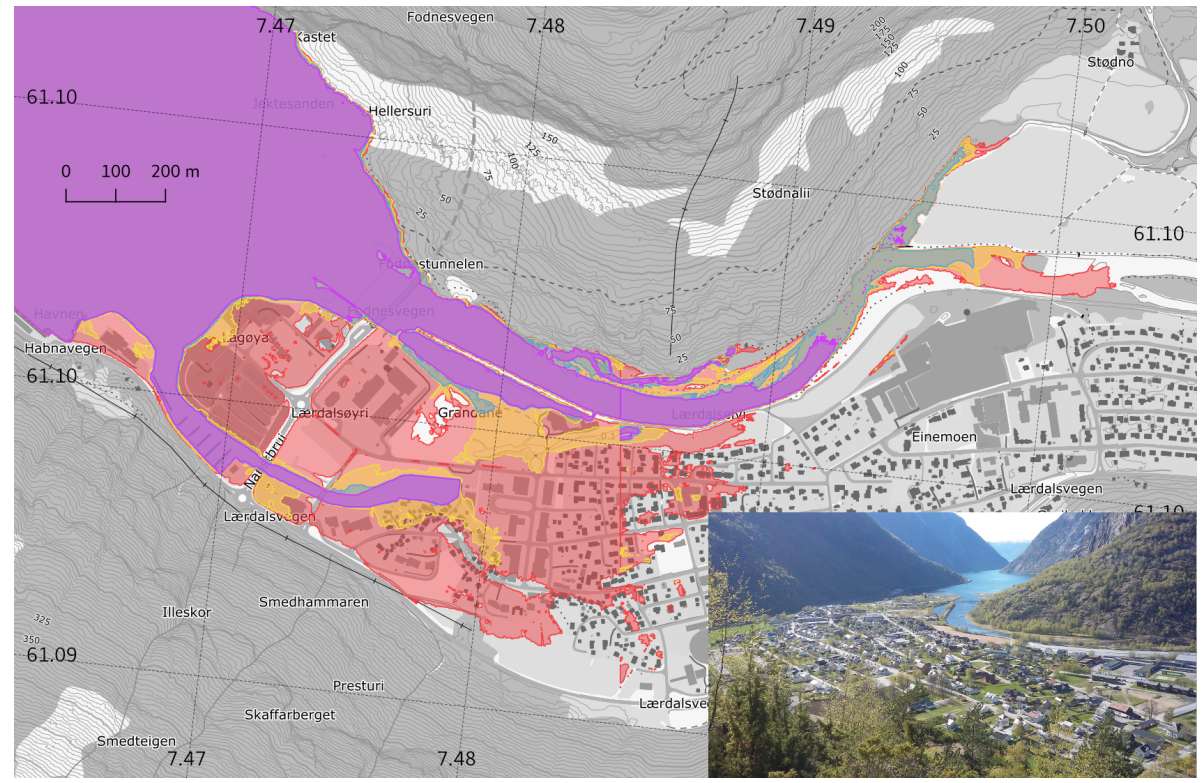

Figure 5. Stack of inundation maps covering the village Lærdalsøyri, located on a glaciofluvial delta at the head of Sognefjorden. Violet: present MHW. Green: MHW for 2090 (0.58 m above present MHW). Orange: present 200-year storm surge (1.00 m above present MHW) Red: 200-year storm surge for 2090 (1.58 m above present MHW). Inset: photo of the village of Lærdalsøyri (photo: Magnhild Aspevik). Map data shown are provided by Geonorge and Norway Digital consortium and subject to the Norwegian License for Open Government Data (NLOD) 2.0 and Creative Commons BY 4.0 (CC BY 4.0).

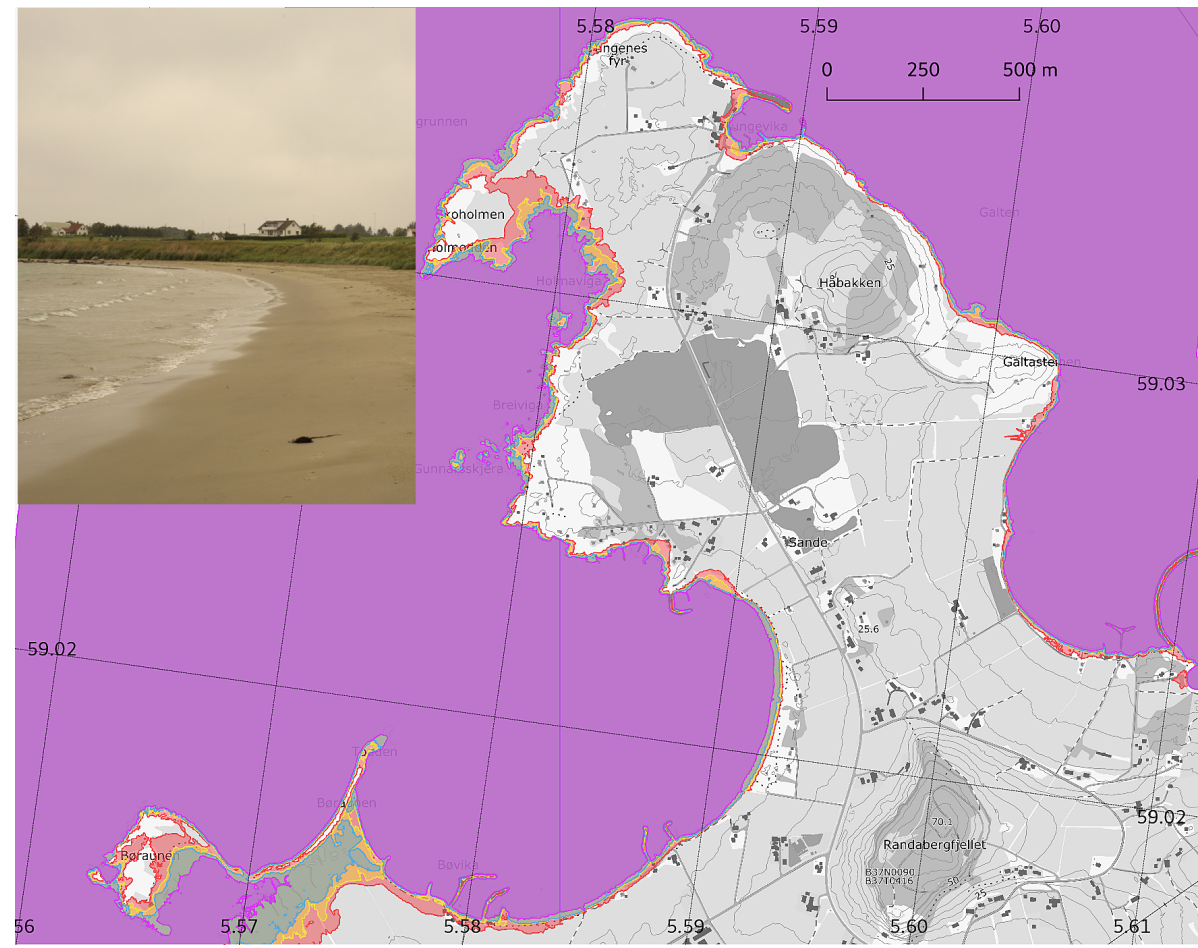

Figure 6. Stack of inundation maps covering Randaberg, located on soft moraine in the southwest of Norway. Violet: present MHW. Green: MHW for 2090 (0.79 m above present MHW). Orange: present 200-year storm surge (0.99 m above present MHW). Red: 200year storm surge for 2090 (1.78 m above present MHW). Inset: soft sand dunes at Sandestranda close to Randaberg. Photo: Oda R. Ravndal. Map data shown are provided by Geonorge and Norway Digital consortium and subject to the Norwegian License for Open Government Data (NLOD) 2.0 and Creative Commons BY 4.0 (CC BY 4.0). 


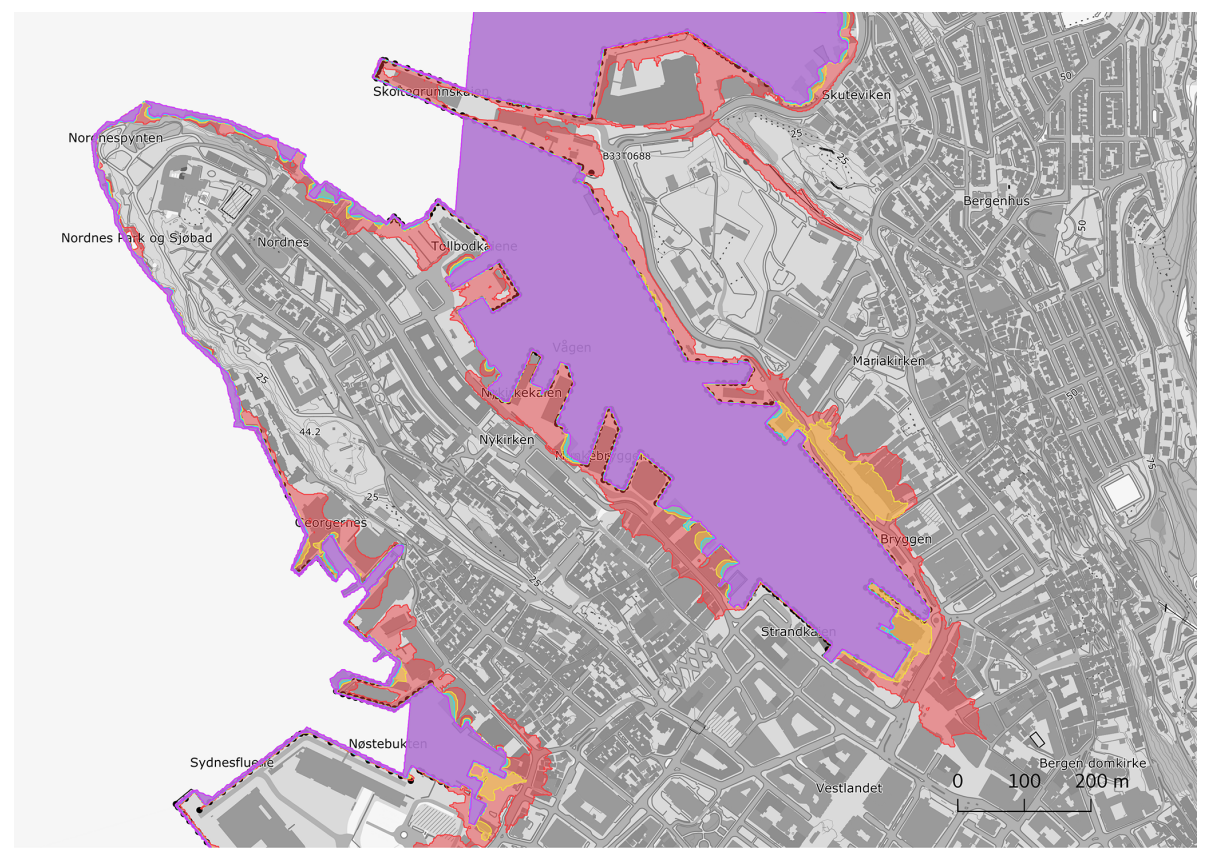

Figure 7. Stack of inundation maps indicating areas affected by coastal flooding in Bergen. Violet: present MHW. Green: MHW at 2090 (0.71 $\mathrm{m}$ above present MHW). Orange: present 200-year storm surge (0.96 m above present MHW). Red: 200-year storm surge for 2090 (1.68 $\mathrm{m}$ above present MHW). Map data shown are provided by Geonorge and Norway Digital consortium and subject to the Norwegian License for Open Government Data (NLOD) 2.0 and Creative Commons BY 4.0 (CC BY 4.0).

may become a problem for the southwestern coast of Norway.

Figure 7 shows how coastal flooding will affect the city of Bergen (population $\sim 240000$ ). This municipality has the highest number of buildings at risk from present and future coastal flooding (Figs. 12 and 13). Although Bergen is characterized by steep terrain that basically prevents large areas from being flooded, the area close to the coast is densely developed. Bergen is also located in a part of Norway with a relatively high projected sea level rise $(0.71 \mathrm{~m})$ as rates of glacial isostatic adjustment are lower than elsewhere; see Figs. 1 and 3. The inundation maps show that projected sea level rise alone (changes in height of MHW) will cause only small changes to the areas that will be permanently inundated. On the other hand, the combined effect of sea level rise and storm surges indicates many more buildings, roads, and piers will be at risk from coastal flooding in the future. Other Norwegian city centers that will become more vulnerable to coastal flooding include Fredrikstad, Sandefjord, Arendal, Mandal, Stavanger, and Troms $\varnothing$. Oslo, the capital of Norway, is generally at lower risk from 21 st century sea level rise.

\subsection{National statistics for land areas, buildings, and roads at risk}

For each coastal municipality, we have calculated the area of land, number of buildings, and length of roads affected by coastal flooding. These categories are further subdivided in order to better understand the details of what is at risk, e.g., land areas are divided into areas that are classified as being developed, nature, public facility, or primary industry (see Table 1 for more details). The numbers of affected objects (i.e., nationwide totals for Norway or at least for the $\sim 80 \%$ of the coast where we have data) are given in Tables $2-4$ and illustrated in Fig. 8. The percentage increase in exposed areas, buildings, and roads between 2017 and 2090 for different sea level scenarios are listed in Table 5.

Our results help quantify the risk of present-day coastal flooding for Norway and how that risk will increase with sea level rise. If we compare totals of what is exposed to a 200year storm surge at present and for 2090, we can broadly see how that risk will evolve nationwide. Total land area exposed will increase from around 400 to $610 \mathrm{~km}^{2}$, total number of buildings from 105000 to 137000 , and total length of roads from 510 to $1340 \mathrm{~km}$. A well-recognized consequence of sea level rise is that present-day storm surge levels will be reached or exceeded far more frequently in the future (for Norway, see Simpson et al., 2017). This is also apparent from our statistics. For example, the numbers of affected objects for the 20-year storm surge return height in 2090 exceed the numbers for the 1000-year storm surge height at present.

For all water levels, Table 2 indicates that the vast majority of flooded land areas fall into two categories; nature and primary industries (see Table 1 for a more detailed description of subcategories). Only a small fraction is categorized as 

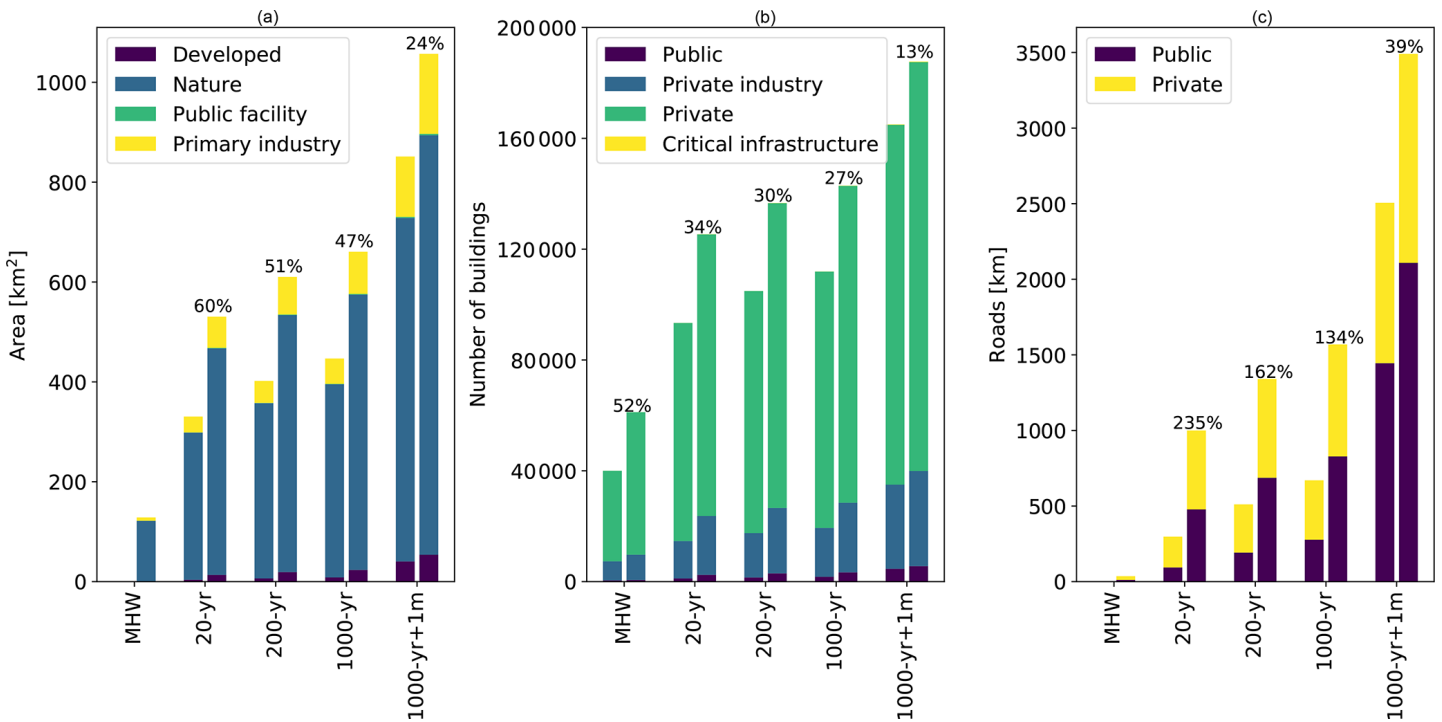

Figure 8. The bars indicate the size of areas (a), the number of buildings (b), and the length of roads (c) affected by sea level rise and storm surge in Norway. For each water level, the left and right bars indicate affected objects at present and for 2090, respectively. Percentages on top of the right-hand bars indicate total change from now to 2090 due to sea level rise.

Table 1. Overview of categories and subcategories of objects potentially exposed to coastal flooding.

\begin{tabular}{|c|c|c|}
\hline Category & Subcategory & Examples of object types \\
\hline \multirow[t]{5}{*}{ Buildings } & Private & homes, cabins, garages, boat houses \\
\hline & Private industry & factories, workshops, storage halls \\
\hline & & $\begin{array}{l}\text { power plants, transformers } \\
\text { agricultural buildings, fish farming facilities } \\
\text { offices, bank buildings, post offices, TV buildings } \\
\text { shopping centers, petrol stations, parking houses } \\
\text { hotels, restaurants, canteen buildings, rental cabins }\end{array}$ \\
\hline & Public & $\begin{array}{l}\text { administration buildings, town halls } \\
\text { waste handling, water supply, pump stations } \\
\text { railway and subway stations, freight terminals } \\
\text { universities, schools, student homes } \\
\text { galleries, libraries, sport halls, } \\
\text { buildings for religious activities } \\
\text { clinics, medical centers, living and service centers } \\
\text { lighthouses, monuments, public toilets }\end{array}$ \\
\hline & Critical infrastructure & $\begin{array}{l}\text { hospitals, ambulance stations, nursing homes } \\
\text { prisons, fire stations }\end{array}$ \\
\hline \multirow[t]{4}{*}{ Areas } & Developed & cities, residential estates, industry areas, airports \\
\hline & Nature & forests, wetlands, fields, glaciers \\
\hline & Public facility & sports facilities, cemeteries \\
\hline & Primary industry & agricultural areas, quarries \\
\hline \multirow[t]{2}{*}{ Roads } & Private & privately owned roads \\
\hline & Public & European routes, highways, county roads, municipality roads \\
\hline
\end{tabular}


Table 2. Affected areas $\left(\mathrm{km}^{2}\right)$ in Norway under different water levels at present and for 2090. Numbers in parentheses indicate the percentage share of the total for each subcategory. Note that the areas for present MHW have been subtracted from the numbers for higher water levels.

\begin{tabular}{llrrrrr}
\hline Scenario & Year & Total & Developed & Nature & $\begin{array}{c}\text { Public } \\
\text { facility }\end{array}$ & $\begin{array}{r}\text { Primary } \\
\text { industry }\end{array}$ \\
\hline MHW & 2090 & 128.5 & $1.0(0.8)$ & $121.0(94.2)$ & $0.0(0.0)$ & $6.6(5.1)$ \\
$20 \mathrm{yr}$ & present & 330.5 & $3.9(1.2)$ & $294.6(89.1)$ & $0.3(0.1)$ & $31.8(9.6)$ \\
$20 \mathrm{yr}$ & 2090 & 530.6 & $13.6(2.6)$ & $453.6(85.5)$ & $1.0(0.2)$ & $62.5(11.8)$ \\
$200 \mathrm{yr}$ & present & 402.0 & $6.4(1.6)$ & $351.0(87.3)$ & $0.6(0.1)$ & $44.0(11.0)$ \\
$200 \mathrm{yr}$ & 2090 & 610.3 & $19.3(3.2)$ & $514.5(84.3)$ & $1.2(0.2)$ & $75.3(12.3)$ \\
$1000 \mathrm{yr}$ & present & 446.8 & $8.5(1.9)$ & $386.8(86.6)$ & $0.7(0.2)$ & $50.7(11.4)$ \\
$1000 \mathrm{yr}$ & 2090 & 660.6 & $23.6(3.6)$ & $551.2(83.4)$ & $1.4(0.2)$ & $84.4(12.8)$ \\
MHW + $1 \mathrm{~m}$ & present & 273.9 & $3.1(1.1)$ & $246.6(90.0)$ & $0.2(0.1)$ & $24.0(8.8)$ \\
$1000 \mathrm{yr}+1 \mathrm{~m}$ & present & 851.3 & $40.5(4.8)$ & $687.8(80.8)$ & $2.1(0.2)$ & $120.8(14.2)$ \\
$1000 \mathrm{yr}+1 \mathrm{~m}$ & 2090 & 1056.8 & $54.0(5.1)$ & $840.0(79.5)$ & $2.8(0.3)$ & $160.1(15.2)$ \\
MHW + 2 m & present & 647.2 & $24.4(3.8)$ & $540.6(83.5)$ & $1.5(0.2)$ & $80.8(12.5)$ \\
MHW + 3 m & present & 1032.5 & $52.5(5.1)$ & $824.3(79.8)$ & $2.6(0.3)$ & $153.0(14.8)$ \\
MHW + 4 m & present & 1379.7 & $69.8(5.1)$ & $1082.8(78.5)$ & $3.8(0.3)$ & $223.2(16.1)$ \\
MHW + 5 m & present & 1719.4 & $84.4(4.9)$ & $1337.7(77.8)$ & $4.9(0.3)$ & $292.5(17.0)$ \\
\hline
\end{tabular}

Table 3. Affected buildings in Norway under different water levels at present and for 2090. Numbers in parentheses indicate the percentage share of the total for each subcategory.

\begin{tabular}{llrrrrr}
\hline Scenario & Year & Total & Private & $\begin{array}{r}\text { Private } \\
\text { industry }\end{array}$ & Public & $\begin{array}{r}\text { Critical } \\
\text { infrastructure }\end{array}$ \\
\hline MHW & present & 40072 & $32677(81.5)$ & $6891(17.2)$ & $448(1.1)$ & $6(0.01)$ \\
MHW & 2090 & 61252 & $51436(84.0)$ & $9122(14.9)$ & $606(1.0)$ & $7(0.01)$ \\
$20 \mathrm{yr}$ & present & 93566 & $78721(84.1)$ & $13512(14.4)$ & $1137(1.2)$ & $22(0.02)$ \\
$20 \mathrm{yr}$ & 2090 & 125904 & $101665(80.7)$ & $21227(16.9)$ & $2457(2.0)$ & $65(0.05)$ \\
$200 \mathrm{yr}$ & present & 105180 & $87370(83.1)$ & $16007(15.2)$ & $1505(1.4)$ & $30(0.03)$ \\
$200 \mathrm{yr}$ & 2090 & 137313 & $109983(80.1)$ & $23614(17.2)$ & $2980(2.2)$ & $80(0.06)$ \\
$1000 \mathrm{yr}$ & present & 112286 & $92523(82.4)$ & $17623(15.7)$ & $1763(1.6)$ & $35(0.03)$ \\
$1000 \mathrm{yr}$ & 2090 & 143684 & $114359(79.6)$ & $25120(17.5)$ & $3362(2.3)$ & $89(0.06)$ \\
$1000 \mathrm{yr}+1 \mathrm{~m}$ & present & 166158 & $129875(78.2)$ & $30369(18.3)$ & $4641(2.8)$ & $151(0.1)$ \\
$1000 \mathrm{yr}+1 \mathrm{~m}$ & 2090 & 189155 & $147591(78.0)$ & $34322(18.1)$ & $5602(3.0)$ & $191(0.1)$ \\
MHW + 1 m & present & 86944 & $72999(84.0)$ & $12735(14.6)$ & $1037(1.2)$ & $12(0.01)$ \\
MHW + 2 m & present & 141649 & $112137(79.2)$ & $25255(17.8)$ & $3391(2.4)$ & $91(0.06)$ \\
MHW + 3 m & present & 185175 & $144329(77.9)$ & $33804(18.3)$ & $5441(2.9)$ & $192(0.10)$ \\
MHW + 4 m & present & 223396 & $175011(78.3)$ & $39345(17.6)$ & $6926(3.1)$ & $258(0.12)$ \\
MHW +5 m & present & 263494 & $208126(79.0)$ & $44777(17.0)$ & $8047(3.1)$ & $331(0.13)$ \\
\hline
\end{tabular}

developed or public facility. This reflects the fact that $94.8 \%$ of Norway's total land area is nature and undeveloped land areas, $3.5 \%$ is agricultural areas, and only $1.7 \%$ is developed (SSB, 2019). However, we note that developed areas exposed to a 200 -year storm surge will increase by $200 \%$ in size between now and 2090 (increasing from 6 to $19 \mathrm{~km}^{2}$; see Tables 2 and 5). A majority of the affected buildings are private homes and private industry, while the fraction of public buildings is small (see Table 3). We have also identified some exposed buildings categorized as critical infrastructure (see Table 1 for definition). These buildings must function during crises because their failure may cause vital public services to break down. It is therefore especially important to identify these buildings so that climate adaptation measures can be taken. Tables 3 and 5 show that the number of buildings categorized as critical infrastructure at risk from coastal flooding will more than double due to projected 21 st century sea level rise (from 30 to 80 buildings for the 200-year storm surge level). For roads that are exposed, there is an approximate balance between private and public roads (Table 4).

There are noticeable differences in the statistics between the different present-day storm surge return heights (see Table 6). The increases from the 20-year to the 200-year present-day storm surge height are $12 \%$ and $22 \%$ for the number of affected buildings and the size of flooded land areas, respectively. The increase from the 200-year to the 
Table 4. Affected roads $(\mathrm{km})$ in Norway under different water levels at present and for 2090. Numbers in parentheses indicate the percentage share of the total for each subcategory. Note that the lengths of affected roads for present MHW have been subtracted from the numbers for higher water levels.

\begin{tabular}{llrrr}
\hline Scenario & Year & Total & Private & Public \\
\hline MHW & 2090 & 36.0 & $24.4(67.8)$ & $11.5(31.9)$ \\
$20 \mathrm{yr}$ & present & 297.7 & $203.7(68.4)$ & $93.9(31.5)$ \\
$20 \mathrm{yr}$ & 2090 & 999.8 & $521.9(52.2)$ & $477.8(47.8)$ \\
$200 \mathrm{yr}$ & present & 511.1 & $318.6(62.3)$ & $192.3(37.6)$ \\
$200 \mathrm{yr}$ & 2090 & 1340.8 & $653.6(48.7)$ & $687.0(51.2)$ \\
$1000 \mathrm{yr}$ & present & 670.3 & $393.0(58.6)$ & $277.2(41.4)$ \\
$1000 \mathrm{yr}$ & 2090 & 1569.0 & $740.5(47.2)$ & $828.4(52.8)$ \\
$1000 \mathrm{yr}+1 \mathrm{~m}$ & present & 2506.0 & $1060.8(42.3)$ & $1445.1(57.7)$ \\
$1000 \mathrm{yr}+1 \mathrm{~m}$ & 2090 & 3490.9 & $1382.2(39.6)$ & $2108.6(60.4)$ \\
MHW $+1 \mathrm{~m}$ & present & 215.4 & $148.4(68.9)$ & $66.9(31.1)$ \\
MHW $+2 \mathrm{~m}$ & present & 1582.6 & $742.2(46.9)$ & $840.3(53.1)$ \\
MHW +3 m & present & 3436.9 & $1358.5(39.5)$ & $2078.4(60.5)$ \\
MHW $+4 \mathrm{~m}$ & present & 5172.7 & $1901.5(36.8)$ & $3271.0(63.2)$ \\
MHW +5 m & present & 6832.2 & $2433.3(35.6)$ & $4398.8(64.4)$ \\
\hline
\end{tabular}

1000 -year present-day storm surge return height is $7 \%$ and $11 \%$ for buildings and areas. For roads, the increase is a lot larger, i.e., the length of roads flooded increases by $72 \%$ between the 20-year and the 200-year present-day storm surge return heights and by $31 \%$ from the 200 -year to the 1000 year return height. Taking into account projected sea level rise for 2090, the increases in affected objects between the different storm surge return heights show a similar pattern to the present day. That is, the increases for higher water levels are more rapid for roads compared to buildings and land areas.

Tables 2-4 also includes numbers for present $\mathrm{MHW}+1$, $2,3,4$, and $5 \mathrm{~m}$, as well as the 1000-year storm surge return height $+1 \mathrm{~m}$ for present and 2090. Global sea level rise will continue after 2100 and these numbers are therefore of use when assessing the consequences of long-term sea level rise. The numbers for $\mathrm{MHW}+5 \mathrm{~m}$ represent the lower limit of the range of eventual global sea level change, as suggested by Strauss et al. (2015). In this scenario, more than $1700 \mathrm{~km}^{2}, 263000$ buildings, and $6800 \mathrm{~km}$ of roads would be permanently flooded if no adaptive measures are taken. The numbers for a 1000-year storm surge $+1 \mathrm{~m}$ sea level rise are smaller than those for $\mathrm{MHW}+5 \mathrm{~m}$ but are still significantly higher than those for 200- and 1000-year storm surge for 2090. The consequences of long-term sea level rise for Norway are profound, will lead to large changes to many coastal cities and to the nature of the coastline, and will require extensive climate adaptation measures.

\subsection{Regional statistics for land areas, buildings, and roads at risk}

Here we present results for each coastal municipality in Norway. Regional differences are useful for identifying the ar- eas of the coast that are most vulnerable to sea level rise and storm surges. We focus on the 200-year storm surge return height but note that the pattern of impacts are broadly similar for other return heights. Figures 9-11 show for each coastal municipality the area of land, number of buildings, and length of roads that are affected by coastal flooding at present and for 2090, respectively.

The municipalities with the largest land areas that are at risk of flooding are located in the middle of Norway (between Trondheim and Troms $\varnothing$ ) and in the outer part of Oslofjorden. This is also evident in Figs. 12a and 13a, which summarize results for the 10 municipalities that have the highest number of affected objects. For the present-day 200-year storm surge return height, 9 of these 10 municipalities are located in the middle of Norway and 1 (Fredrikstad) in outer Oslofjorden. When considering flooded land area as a percentage of the total municipality area (Fig. 9c and d), we find that 6 of the 10 municipalities with the highest percentages are located on the western coast. For 2090, the size of the flooded area increases and the order of the municipalities changes slightly, but the general pattern of regional impacts does not change.

The regional pattern of land areas affected by coastal flooding closely corresponds to regional differences in the storm surge return heights, although regional differences in topography and projected sea level rise also play a role to some extent. The exposure of land areas to coastal flooding is one measure of the impacts of 21 st century sea level rise and storm surge. As mentioned above, the majority (>80\%) of these land areas are classified as nature. Several of the municipalities in the middle of Norway, where the largest land areas are flooded, are sparsely populated. This is also evident from the maps visualizing the distribution of affected buildings (Fig. 10), which have quite different spatial patterns. For buildings, the consequences of storm surge flooding are particularly large in two counties, Hordaland and Rogaland, which are on the western coast of Norway. Moreover, many buildings are exposed along the outer parts of Oslofjorden, along the southern coast, around Trondheimsfjorden, in Lofoten, and in Troms $\emptyset$. These regions stand out as they are densely populated and include several of the largest cities in Norway.

The pattern of exposed roads (Fig. 11) is similar to that for land areas, but the 10 most exposed municipalities also include some locations along the southernmost part of the coast.

\section{Discussion}

\subsection{Accuracy of the DEM}

The project goal uncertainty (RMSE) of the lidar data, from which the DEM is interpolated, is $0.1 \mathrm{~m}$ (Kartverket, 2014). This is ensured by comparing and fitting the point cloud of lidar measurements to control fields and road tracks 
Table 5. The percentage increase in exposed areas, buildings, and roads between 2017 and 2090 for different sea level scenarios.

\begin{tabular}{llrrrc}
\hline Category & Subcategory & $20 \mathrm{yr}$ & $200 \mathrm{yr}$ & $1000 \mathrm{yr}$ & $1000 \mathrm{yr}+1 \mathrm{~m}$ \\
\hline \multirow{2}{*}{ Area } & Total & 61 & 52 & 48 & 24 \\
& Developed & 249 & 202 & 178 & 33 \\
& Nature & 54 & 47 & 43 & 22 \\
& Public facility & 233 & 100 & 100 & 33 \\
& Primary industry & 97 & 71 & 66 & 33 \\
\hline \multirow{2}{*}{ Buildings } & Total & 35 & 31 & 28 & 14 \\
& Private & 29 & 26 & 24 & 14 \\
& Private industry & 57 & 48 & 43 & 13 \\
& Public & 116 & 98 & 91 & 21 \\
& Critical infrastructure & 195 & 167 & 154 & 26 \\
\hline \multirow{2}{*}{ Roads } & Total & 236 & 162 & 134 & 39 \\
& Private & 156 & 105 & 88 & 30 \\
& Public & 409 & 257 & 199 & 46 \\
\hline
\end{tabular}

Table 6. The percentage increase in exposed areas, buildings, and roads between different storm surge return heights at present and for 2090.

\begin{tabular}{lcrrr}
\hline Category & $\begin{array}{c}20 \rightarrow 200 \mathrm{yr} \\
\text { present }\end{array}$ & $\begin{array}{r}200 \rightarrow 1000 \mathrm{yr} \\
\text { present }\end{array}$ & $\begin{array}{r}20 \rightarrow 200 \mathrm{yr} \\
2090\end{array}$ & $200 \rightarrow \begin{array}{r}1000 \mathrm{yr} \\
2090\end{array}$ \\
\hline Area & 22 & 11 & 15 & 8 \\
Buildings & 12 & 7 & 9 & 5 \\
Roads & 72 & 31 & 34 & 17 \\
\hline
\end{tabular}

with heights observed by Global Navigation Satellite Systems (GNSS). Both control fields and road tracks must be considered favorable lidar targets. The actual accuracy of the interpolated DEM depends on the slope of the terrain, terrain surface complexity, target reflectivity, canopy coverage and near ground vegetation, the density and distribution of the ground returns, the accuracy of the lidar system, the interpolation algorithm used to create the DEM from the source data, and the spatial resolution of the DEM (e.g., Reutebuch et al., 2003; Li, 1992). Furthermore, transforming ellipsoidal heights to the national height system (NN2000) may introduce additional errors. As heights observed by both GNSS and lidar are transformed to NN2000 using the same HREF model, any errors in the transformation will not be detected by comparison to the GNSS control measurements. We therefore consider the project goal uncertainty of the lidar data as an optimistic error estimate for the DEM in the coastal zone.

The accuracy of a DEM can be assessed by comparing it to surveyed control points located in various types of terrain. For example, Gesch (2009) assessed elevation data over eastern North Carolina, USA, by comparing it to 489 control points the National Geodetic Survey uses for gravity and geoid modeling. These points were surveyed by GNSS. Poulter and Halpin (2008) followed a similar approach that also focused on North Carolina but used 3480 quality control points surveyed by real-time kinematic GNSS.
We assess the quality of Norway's DEM using two independent sets of control points surveyed by GNSS. The first dataset includes about 10000 points that are part of the Norwegian national geodetic network (NGN). These points are spread throughout Norway in various types of terrain and topography and are in locations suitable for making GNSS measurements (i.e., sites are chosen where obstacles that could interrupt the GNSS signals are avoided). An adjustment of baselines and 3-D positions of individual benchmarks was used to compute final heights with typical standard errors of less than $1 \mathrm{~cm}$. The second dataset consists of 132 points observed with the Norwegian real-time kinematic GNSS network service, known as CPOS (Ouassou et al., 2015). The test field covered an area of approximately $0.2 \mathrm{~km}^{2}$ and was located in typical Norwegian coastal terrain including exposed bedrock, slopes, and beaches covered with boulders. As these points were surveyed with CPOS, we expect that the heights in the test field have slightly lower accuracy compared to the NGN, approximately 2 to $3 \mathrm{~cm}$. All heights observed by GNSS were transformed to NN2000 by use of HREF. For both groups of control points, we estimated the maximum, minimum, and mean difference as well as the RMSE. Table 8 summarizes the results of the comparison.

Comparing the nationwide DEM to the heights of the NGN reveals large differences ranging up to $\sim 62 \mathrm{~m}$. Many of the largest differences are for control points located on the roofs of high buildings or in open-pit mines where the ter- 

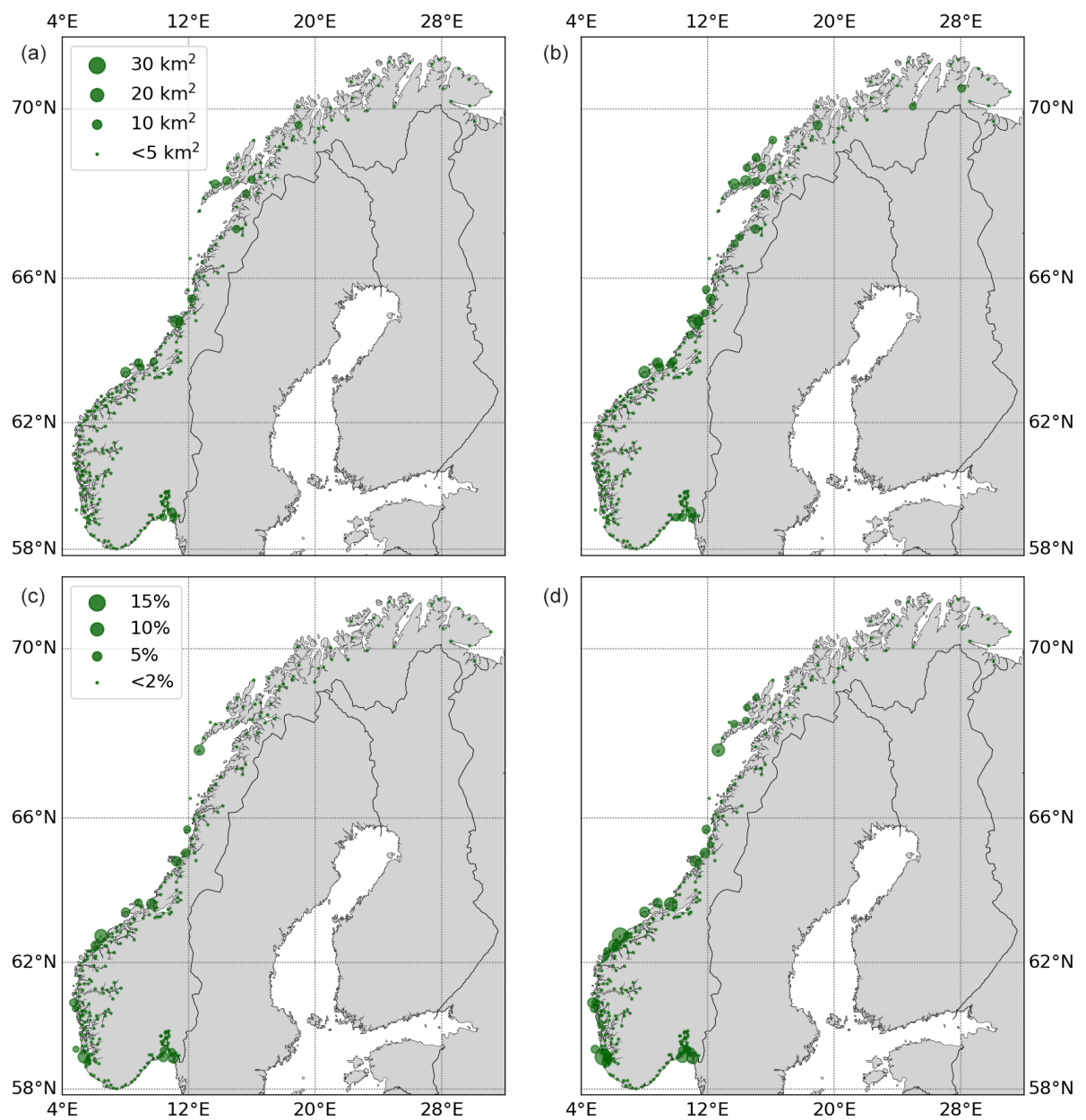

Figure 9. Affected land areas due to a 200-year storm surge hazard at present (a, c) and for 2090 (b, d). The radius of the bubbles for each municipality is proportional to the size of flooded land area $(\mathbf{a}, \mathbf{b})$ and flooded land areas as a percentage of the municipality's total area (c, d).
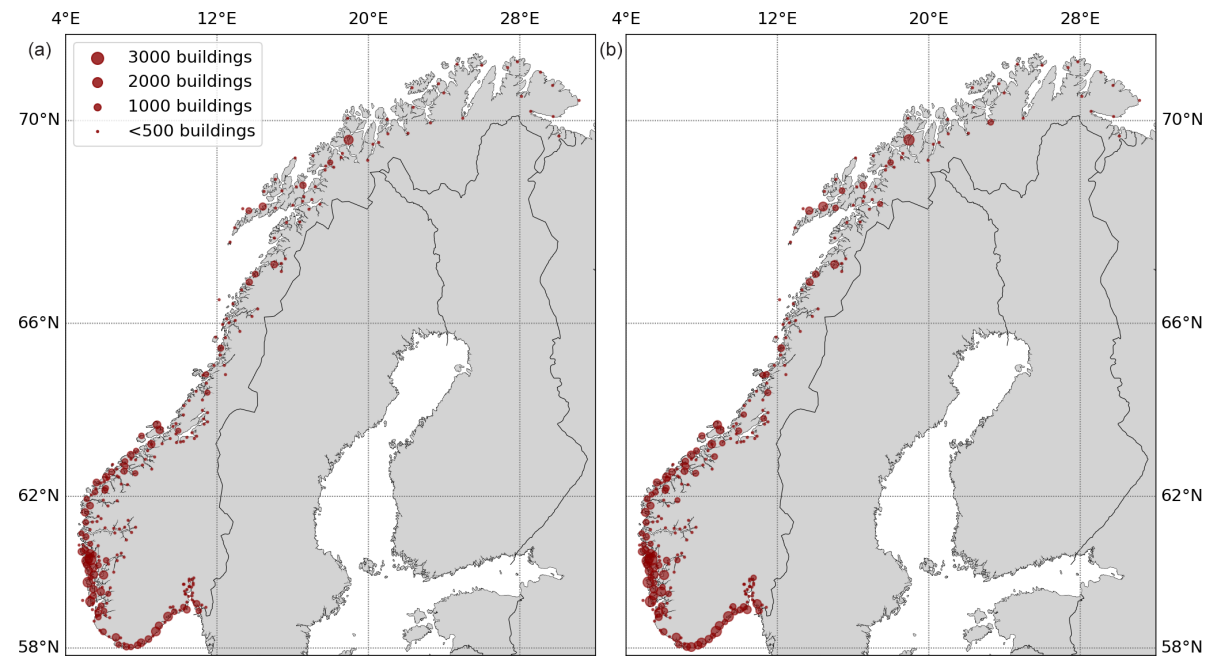

Figure 10. Affected buildings due to a 200-year storm surge hazard at present (a) and for 2090 (b). The radius of the bubbles are proportional to the number of exposed buildings. 

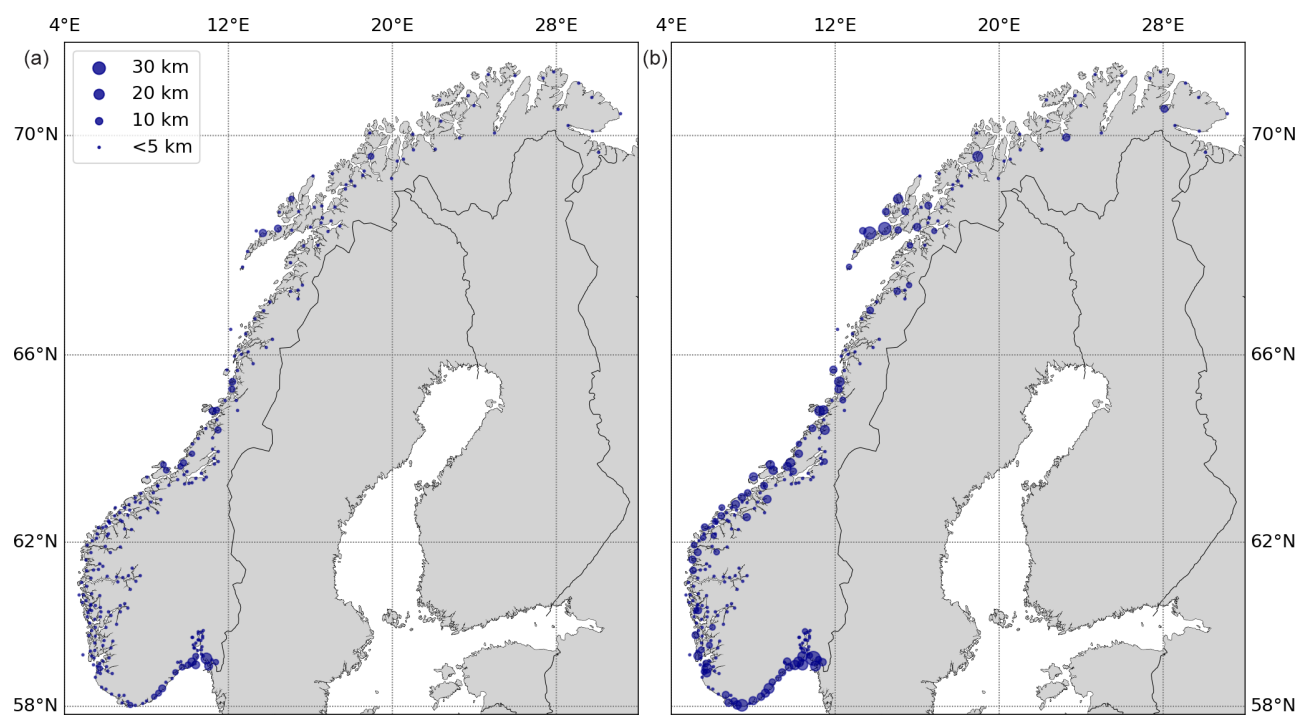

Figure 11. Affected roads due to a 200-year storm surge hazard at present (a) and for 2090 (b). The radius of the bubbles are proportional to the length of exposed roads.

rain has changed due to human activity. We therefore opt to eliminate these outliers, and focus on control points within $\pm 1 \mathrm{~m}$ from the DEM only. For these remaining points, the mean difference is $-0.12 \mathrm{~m}$ and RMSE is $0.26 \mathrm{~m}$. The negative bias indicates that the DEM has systematically lower heights than the NGN. Benchmarks located at high points in the terrain may partly explain this bias. For instance, many of the benchmarks in NGN are placed on small concrete pillars with horizontal dimensions of $0.5 \mathrm{~m} \times 0.5 \mathrm{~m}$ and a height of approximately $0.25 \mathrm{~m}$ above its local surrounding terrain. Such features are not picked up by the DEM because the area of the pillars amounts to only one-fourth of a cell in the DEM. Additionally, the algorithm used to convert the lidar data from a point cloud to a regular grid may contribute to the bias. The generalization can be considered to be applying a low pass filter to the terrain, with the effect of filtering out the finest details in the terrain. The RMSE of $0.26 \mathrm{~m}$ is similar to that calculated by Poulter and Halpin (2008) for a $6 \mathrm{~m} \times 6 \mathrm{~m}$ DEM covering North Carolina but significantly higher than $0.14 \mathrm{~m}$ estimated by Gesch (2009) for the $3 \mathrm{~m} \times 3 \mathrm{~m}$ United States Geological Survey (USGS) National Elevation Dataset also covering North Carolina.

Comparing the DEM to the points in the coastal test area, we calculate a mean difference of $0.11 \mathrm{~m}$ and RMSE of $0.28 \mathrm{~m}$. The coastal test field also has points with differences larger than $1 \mathrm{~m}$, these points are located in steep terrain close to the sea. Using observations from flat terrain only, the mean difference and the RMSE reduce to -0.01 and $0.10 \mathrm{~m}$, respectively. We repeat the calculations by replacing the nationwide DEM with a DEM with a finer spatial resolution $(0.5 \mathrm{~m} \times 0.5 \mathrm{~m})$ that covers most of the test field. Using a finer spatial resolution acts to reduce the overall RMSE by $44 \%$ and several of the largest differences also become smaller (see Table 8). This indicates that the vertical accuracy of the DEM can be significantly improved by increasing the spatial resolution to above $1 \mathrm{~m} \times 1 \mathrm{~m}$, especially in steep terrain.

Our tests suggest that the interpolated DEM used to calculate the inundation maps only achieves the project goal uncertainty of the lidar data (RMSE $<0.1 \mathrm{~m}$ ) in flat terrain. Considerably lower accuracies must be expected in steep areas and along much of the coast. The comparison to control points in the national geodetic network indicates a RMSE of $0.26 \mathrm{~m}$ to be a more realistic error estimate. As the control points in NGN are located in different types of terrain, which broadly reflect Norway's varying physical geography, we believe they provide a more appropriate DEM quality indicator rather than comparisons to measurements at idealized control surfaces and road tracks as used to determine the project goal RMSE.

Any error in the DEM translates into horizontal errors when mapping the extent of a water level or flood surface. For a particular section, the overall horizontal deformation can be written $\epsilon / \tan (\alpha)$, where $\epsilon$ is the uncertainty of the DEM and $\alpha$ is the slope of the terrain. In steep terrain, we expect that the DEM has its largest errors but that the horizontal deformation due to a large vertical error will be small. In flat terrain, it is the opposite; the DEM is typically more accurate, but a smaller vertical error may introduce larger horizontal deformations. For example, a DEM error of $0.26 \mathrm{~m}$ will deform the line that delineates a flood surface by 2.97 and $0.71 \mathrm{~m}$ for a 5 and $20^{\circ}$ slope, respectively. From this we can summarize that, although Norway has a generally steep coastal topography, the relative large DEM errors here will not introduce large horizontal errors when mapping flood levels. However, given the length of the coast and the large 

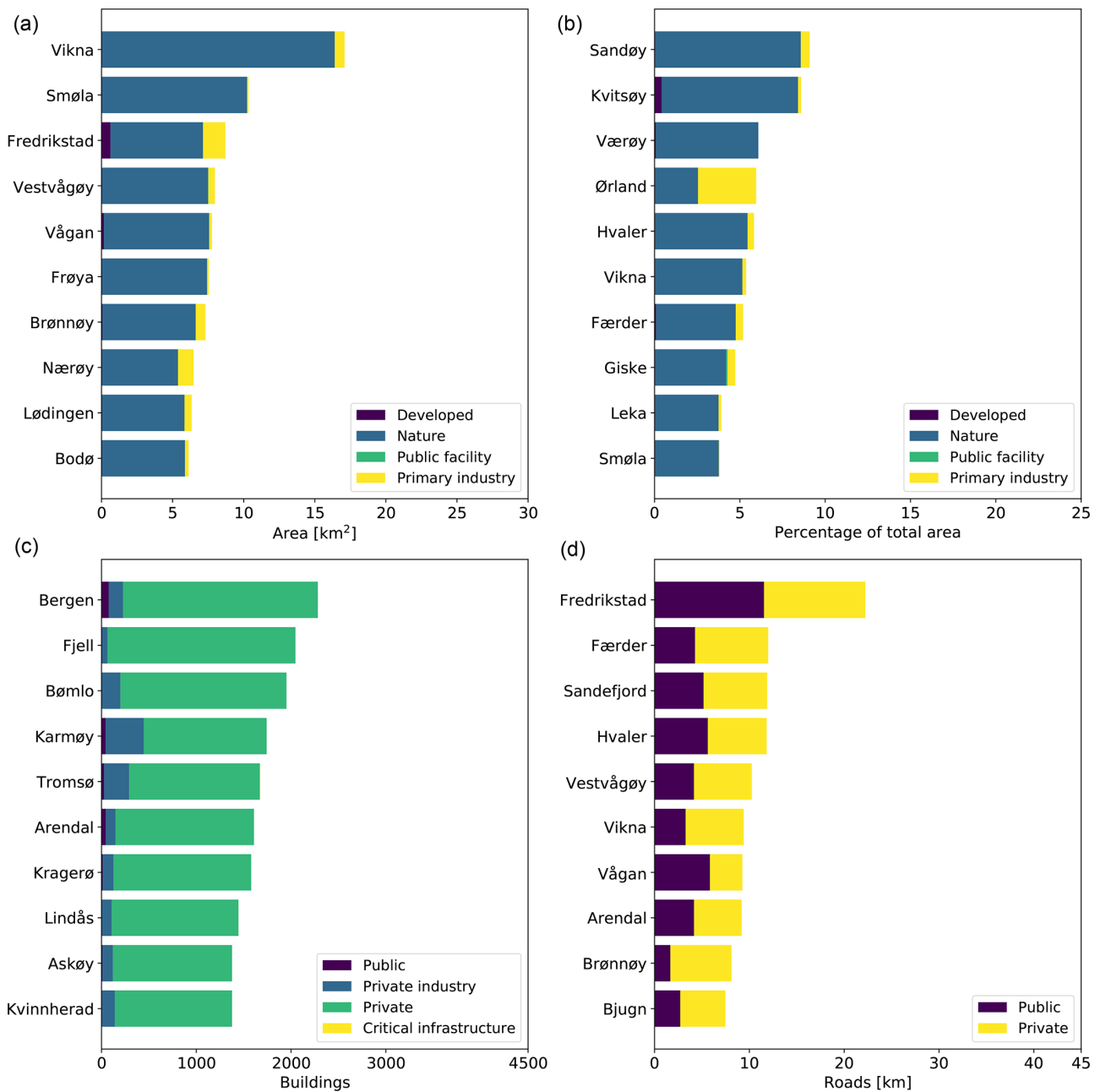

Figure 12. The 10 municipalities with the most land area (a, b), buildings (c), and roads (d) affected by a 200-year storm surge hazard at present sea level.

amount of infrastructure located very close to the coastline, the DEM errors may be critical for determining which objects are at risk.

\subsection{Uncertainties of mapping}

A number of different factors determine the accuracy of the inundation maps and associated statistics of exposed objects. Although the uncertainties attached to these factors are not accounted for in our analysis, we discuss their relative importance to the results. Factors determining the accuracy of our results include uncertainties related to (1) the DEM, (2) the vertical reference frame NN2000, (3) the transformation of ellipsoidal heights to the national height system (HREF), (4) the height determined for mean sea level and MHW, (5) the estimated storm surge return heights, (6) the sea level projections, (7) the horizontal position of buildings and roads, (8) inaccurate polygons defining land cover, and (9) the effect of, for example, buildings on pillars and piers. We note that these factors and their uncertainties are inherently different. Furthermore, not all of these factors are relevant for all of the water levels we have mapped. Uncertainties related to storm surge heights are, for example, not relevant when mapping MHW.

When assessing future flood risk the largest uncertainty probably relates to the sea level projections (see Table 7). The sea level projections have uncertainties related to the future emission scenario and the ability of models to simulate the future sea level response. For the mapping method approach taken here, however, where sea level rise is considered a fixed number (95th percentile of RCP8.5), the uncertainty associated with the sea level projections can be ignored. In this situation, planning policy dictates which sea level number to use, but there will nevertheless be mapping uncertainties related to, for example, the accuracy of the DEM and tidal datums. Given the accuracy of the DEM used in this study (0.26 m RMSE), each water level will be mapped with a dif- 

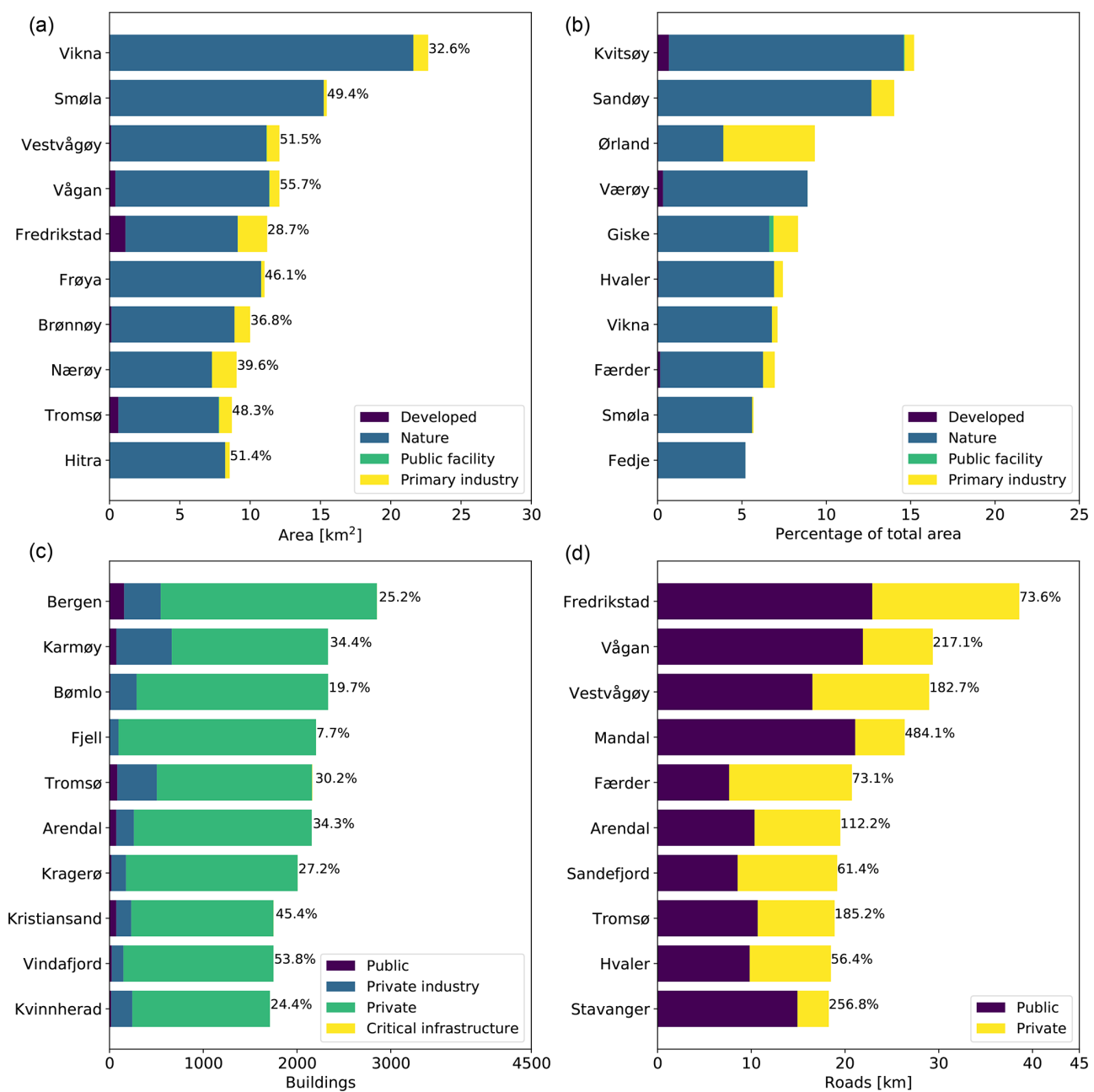

Figure 13. Similar to Fig. 12 but for 2090. The percentages indicate the total change from now to 2090 due to sea level rise.

ferent level of confidence because the lower levels are close to the inherent noise level of the DEM.

In Norway, MHW corresponds to the height of the M2 tidal constituent above mean sea level. The uncertainty of MHW therefore depends on the definition of mean sea level, the uncertainty of the estimated amplitude of M2, and the height difference between MHW and NN2000. In addition, other tidal constituents give small contributions to the mean high tide that the present definition of MHW does not include. Unfortunately, there are no assessments of the uncertainty of MHW along the Norwegian coast. However, what we can say is that the tidal datums, storm surge levels, and their heights with respect to NN2000 are well known in areas close to the tide gauges. Along other parts of the coast, they are less well defined. Uncertainties associated with the tidal datums and storm surge levels may therefore exceed the project goal uncertainty (RMSE $<0.1 \mathrm{~m}$ ) of the elevation data in some areas.

There are also effects that are not included in our analysis; for example, wave setup and runup, changes in tides due to sea level rise, coastal erosion, and the effects of river flooding close to the coast. We have assumed no future changes to the storm surge return heights but note that a recent study projects areas of increase, areas of decrease, and also areas of model disagreement along the Norwegian coast (Vousdoukas et al., 2018b).

In summary, a preliminary assessment indicates that the elevation model (RMSE $0.26 \mathrm{~m}$ ) is the largest source of uncertainty in our mapping method. There are also smaller errors associated with different vertical datums and transformations between datums that have not been assessed for the entire coast. However, we believe that the sum of these mapping errors are generally smaller than the projected sea level rise, which gives us confidence in our results. Future work should look at how these uncertainties can be incorporated into our mapping and web tool (Gesch, 2013, 2018; Cooper and Chen, 2013; Cooper et al., 2013). 
Table 7. Quantitative assessment of effects contributing to the accuracy of the mapping.

\begin{tabular}{|c|c|c|}
\hline Contributor to uncertainty & Uncertainty $[\mathrm{m}]$ & Comment and/or reference \\
\hline DEM & 0.26 & DEM's estimated RMSE \\
\hline HREF & $0.01-0.10$ & $\begin{array}{l}\text { Olav Vestøl, personal communication, } 2019 \\
\text { at the Norwegian Mapping Authority }\end{array}$ \\
\hline Height of MSL in NN2000 & $0.02-0.10$ & Simpson et al. (2015) \\
\hline Height of MHW in NN2000 & Unknown & \\
\hline $\begin{array}{l}\text { Mean range of } 95 \% \text { confidence } \\
\text { intervals for } 20 \text {-year storm surges } \\
\text { along the Norwegian coast }\end{array}$ & 0.15 & Simpson et al. (2015) \\
\hline $\begin{array}{l}\text { Mean range of } 95 \% \text { confidence } \\
\text { intervals for } 200 \text {-year storm surges } \\
\text { along the Norwegian coast }\end{array}$ & 0.21 & Simpson et al. (2015) \\
\hline $\begin{array}{l}\text { Mean range of } 95 \% \text { confidence } \\
\text { intervals for } 1000 \text {-year storm surges } \\
\text { along the Norwegian coast }\end{array}$ & 0.25 & Simpson et al. (2015) \\
\hline Projections of future sea level for 2090 & $>0.5$ & $\begin{array}{l}\text { Range of models, assessed to be } 66 \% \text { of } \\
\text { the total possible outcome for the pathway }\end{array}$ \\
\hline Horizontal position of buildings & $0.2-2$ & Effect depends on slope of terrain \\
\hline Horizontal position of roads and areas & $2-50$ & Effect depends on slope of terrain \\
\hline
\end{tabular}

Table 8. Comparisons of heights from DEMs and heights observed by GNSS. Two DEMs have been assessed, i.e., a nationwide DEM with a spatial resolution of $1.0 \mathrm{~m} \times 1.0 \mathrm{~m}$ and a regional DEM with a spatial resolution of $0.5 \mathrm{~m} \times 0.5 \mathrm{~m}$ covering a smaller test field.

\begin{tabular}{llrrrrr}
\hline Dataset & $\begin{array}{l}\text { Surveying } \\
\text { method }\end{array}$ & $\begin{array}{r}\text { Minimum } \\
\text { difference } \\
{[\mathrm{m}]}\end{array}$ & $\begin{array}{r}\text { Maximum } \\
\text { difference } \\
{[\mathrm{m}]}\end{array}$ & $\begin{array}{r}\text { Mean } \\
\text { difference } \\
{[\mathrm{m}]}\end{array}$ & $\begin{array}{r}\text { RMSE } \\
{[\mathrm{m}]}\end{array}$ & $\begin{array}{r}\text { Number of } \\
\text { observations }\end{array}$ \\
\hline$h_{\mathrm{NGN}}-h_{1.0 \times 1.0}$ (overall) & Network & -61.772 & 4.866 & -0.338 & 1.92 & 10301 \\
$h_{\mathrm{NGN}}-h_{1.0 \times 1.0}$ & Network & -1.000 & 1.000 & -0.116 & 0.259 & 9703 \\
$h_{\mathrm{CPOS}}-h_{1.0 \times 1.0}$ (overall) & CPOS & -0.577 & 1.104 & 0.108 & 0.282 & 132 \\
$h_{\mathrm{CPOS}}-h_{1.0 \times 1.0}$ (flat terrain) & CPOS & -0.255 & 0.395 & -0.008 & 0.096 & 75 \\
$h_{\mathrm{CPOS}}-h_{0.5 \times 0.5}$ (overall) & CPOS & -0.21 & 0.884 & 0.011 & 0.158 & 134 \\
$h_{\mathrm{CPOS}}-h_{0.5 \times 0.5}$ (flat terrain) & CPOS & -0.21 & 0.349 & -0.031 & 0.088 & 73 \\
\hline
\end{tabular}

\subsection{Comparison to other studies and future work}

As an alternative to our approach where affected objects were identified by overlaying inundation polygons with geospatial data like buildings, the height of the objects themselves can be used to identify what is exposed to future sea level rise and storm surges. Almås and Hygen (2012) followed this approach and used a DEM (unknown spatial resolution but likely a $10 \mathrm{~m} \times 10 \mathrm{~m}$ horizontal resolution with a $2-3 \mathrm{~m}$ vertical error at best) to determine heights of buildings in the coastal zone. In their study, approximately 110000 buildings were found nationwide with a height less than $1 \mathrm{~m}$ above elevation zero in the former national vertical reference system of Norway, NN1954, which at Norwegian tide gauges has its zero height within -0.09 and $0.17 \mathrm{~m}$ from mean sea level.
Unfortunately, a straightforward comparison of the findings of Almås and Hygen (2012) with our results (Table 3) is not possible. Firstly, this is because we have not analyzed affected buildings for a fixed height but have taken into account tidal variations. This will likely make a significant difference because MHW ranges from a couple of centimeters to $1.1 \mathrm{~m}$ a.m.s.l. (above mean sea level) in Norway. If not taken into account, the flooding risk will be underestimated in areas with mean high tide elevation exceeding $0 \mathrm{~m}$, and comparisons across regions with different tidal levels will be compromised (Strauss et al., 2012). Secondly, we have used NN2000 as vertical reference frame instead of NN1954. At the tide gauges along the Norwegian coast, the difference between these two vertical reference frames varies between 
-15 and $12 \mathrm{~cm}$ (Simpson et al., 2015). Thirdly, the numbers in Table 3 are based on data that cover $80 \%$ of the coast, while the study by Almås and Hygen (2012) covers the entire coast. If we still attempt to compare numbers, the water level MHW $+1 \mathrm{~m}$ is perhaps the most similar to the height used in their analysis. For MHW $+1 \mathrm{~m}$ our results show 86944 affected buildings, which is significantly less than the $\sim 110000$ reported by Almås and Hygen (2012). Note that MHW $+1 \mathrm{~m}$ in most areas will be higher than height $1 \mathrm{~m}$ in NN1954.

The bathtub approach applied in the present study results in maps that are consistent with national guidelines on how to account for future sea level change and storm surge in coastal planning. Currently, there are no regulations for modeling the effects of waves, which may increase mean sea level during a storm and introduce geomorphological changes due to erosion and transport of sediments. Modeling the effects of waves should be addressed in future work and will require a more advanced framework than the bathtub approach. A more advanced framework is provided by the open-source numerical model XBeach (Roelvink et al., 2009), which is developed to simulate the effects of storms on sandy coasts with domain size of kilometers. The XBeach model is not a tool for analyzing the entire Norwegian coast but is suitable for case studies of vulnerable areas like beaches and coasts covered by soft sediments (e.g., southwest of Norway).

The present study does not aim to be a socioeconomic analysis of coastal flooding for Norway, as the climate service includes no information on value of property or the population in the coastal zone. Our inundation maps, however, could be used as input to a socioeconomically analysis. In their analysis, Vousdoukas et al. (2018a) caution that the accuracy of their modeled extreme sea levels for Norway may be affected by the presence of many bays, islands, and steep complex terrain. Furthermore, they indicate that elevation data of higher spatial resolution are required to achieve the same accuracy for Norway as for flatter parts of Europe. This suggests that high-accuracy national coastal flooding maps must be used to achieve results that are useful for planners and stakeholders. We believe that the methods and data used for mapping sea levels in the present study, especially the use of a $1 \mathrm{~m} \times 1 \mathrm{~m}$ DEM and accounting for regional differences in MHW, storm surge heights and sea level rise, represent significant progress compared to the methods used by Almås and Hygen (2012) and Vousdoukas et al. (2018a).

\section{Conclusions}

Using new high-accuracy lidar elevation data we have generated coastal flooding maps for Norway. Thus far, we have mapped $\sim 80 \%$ of the coast, for which we currently have data of sufficient accuracy to perform our analysis. Our mapping method accounts for regional variations in tidal datums, storm surge levels, and projections of sea level rise.
Nationwide we have identified a total area of $400 \mathrm{~km}^{2}$, 105000 buildings, and $510 \mathrm{~km}$ of roads that are at risk of flooding from a 200-year storm surge event at present. These numbers will increase to $610 \mathrm{~km}^{2}, 137000$, and $1340 \mathrm{~km}$ with projected sea level rise to 2090 (95th percentile of RCP8.5 as recommended in planning). If sea level rise exceeds the projections by $1 \mathrm{~m}$, then an area of $1060 \mathrm{~km}^{2}$, 189000 buildings, and $3490 \mathrm{~km}$ of roads would be exposed to 1000-year storm surge. This gives an indication of how vulnerable Norway is to a scenario of rapid ice melt from Antarctica. Notably, we also find that the numbers of affected objects for a 20-year storm surge return height in 2090 will exceed the numbers for the 1000-year storm surge at present, indicating that an increasing number of objects will be at risk of more frequent flooding.

Examining the categories of what is at flooding risk shows the vast majority of areas are classified as nature. However, the fraction of total area classified as developed, public facility, or primary industry increases for higher water levels. Developed areas at flooding risk from a 200-year storm surge will increase more than three times in size between now and 2090 due to sea level rise (increasing from 6 to $19 \mathrm{~km}^{2}$ ). For buildings, around $80 \%$ of those at risk are private (homes, cabins, garages, or boat houses) for all mapped water levels. The fraction of buildings classified as private industry, public, or critical infrastructure increases for higher water levels. Critical infrastructure buildings at risk from a 200 -year storm surge will increase from 30 to 80 between now and 2090. For roads, the percentage of public roads at risk will increase for higher water levels. Thus, while sea level rise leads to more objects being at risk of flooding, our results also indicate an increasing fraction will be objects of higher value.

Regional differences indicate that the western and southern coast of Norway, outer parts of Oslofjorden, areas around Trondheimsfjorden, and Troms $\emptyset$ have the largest numbers of buildings at risk of coastal flooding. For land areas and roads, it is the middle of Norway and outer Oslofjorden that are most at risk. Regional differences in the number of objects exposed to flooding can largely be explained by regional differences in population density. Inspection of the inundation maps shows that, across much of Norway, the typically steep topography restricts flooding to areas immediately adjacent to the coast. Of the examples we have examined, we find cities, island communities, and in particular towns and villages located on glaciomarine deltas are at risk from coastal flooding. The flooding risk at glaciomarine deltas can be exacerbated by the effect of river flooding.

A number of different factors determine the accuracy of the mapping and associated statistics of exposed objects. A comparison of control points from different terrain types indicates that the elevation model has a RMSE of $0.26 \mathrm{~m}$ and is the largest source of uncertainty in our mapping method. There are also smaller errors associated with different vertical datums and transformations between datums that have 
not been assessed for the entire coast. However, we believe that the sum of these mapping errors are generally smaller than the projected sea level rise, which gives us confidence in our results. Despite the generally steep nature of the coastline, where any mapping errors introduce only small errors in the horizontal extent of flooding, the sheer length of the coast means that small errors can accumulate. A lot of infrastructure is located very close to the coast and may therefore be erroneously mapped as exposed (or not at risk). Furthermore, objects situated directly above the water surface, e.g., buildings on pillars and roads over bridges, will be erroneously mapped as exposed and cannot be sieved from our results. Owing to this, some results will be biased high. For example, we find 40000 buildings and $180 \mathrm{~km}$ of roads erroneously mapped as exposed to present MHW, when the true number should be zero.

Although Norway is generally at low risk from sea level rise largely owing to its steep topography, the maps presented here show that on local scales, many parts of the coast are potentially vulnerable to flooding. Norway is a welldeveloped country, with expensive infrastructure, properties of high commercial value, and buildings of high standard. These factors raise the potential costs of flooding but make climate adaptation measures more cost effective. Our coastal flooding maps and associated statistics are freely available and, alongside the development of the coastal climate service Se havnivå i kart, will help communicate the risks of sea level rise and storm surge to stakeholders. This will in turn aid coastal management and climate adaptation work in Norway. Users should keep in mind that our maps help identify areas of potential risk, rather than provide exact answers, and that there are uncertainties related to the mapping method and physical processes (e.g., waves) not included here. For planning decisions, a site visit and additional analysis may therefore be appropriate.

Data availability. The coastal inundation maps and the light detection and ranging (lidar) elevation data are freely available at https://kartkatalog.geonorge.no/metadata/ fbb95c67-623f-430a-9fa5-9cfcea8366b3 (last access: 24 February 2020) and https://hoydedata.no/LaserInnsyn/ (last access: 24 February 2020), respectively (Geonorge, 2019; Kartverket, 2014). Sea level projections and storm surge return heights for Norway can be accessed through an application programming interface at http://api.sehavniva.no/tideapi_en.html (last access: 24 February 2020) (see api.sehavniva.no/tideapi_protocol.api). Statistics over flooded objects are available at https: //www.kartverket.no/en/sehavniva/visualize-sea-level/ (last access: 24 February 2020) (Simpson et al., 2015, 2017; Kartverket, 2019c).

Author contributions. KB and MJRS wrote the paper, analyzed and interpreted the statistics, and made all of the figures. EK did the GIS analysis and configured the system for producing inundation maps and associated statistics. ORR contributed materials to the GIS analysis. All authors are members of the team developing and maintaining the coastal climate service Se havnivå i kart.

Competing interests. The authors declare that they have no conflict of interest.

Acknowledgements. The authors are thankful to Magnhild Aspevik, who provided the photo from Lærdalsøyri (see Fig. 5) and the development team behind the open-source QGIS software used to create the presented inundation maps. Map data shown are provided by Geonorge and Norway Digital consortium.

Review statement. This paper was edited by Paolo Tarolli and reviewed by Dean Gesch and Jordan Eamer.

\section{References}

Almås, A.-J. and Hygen, H. O.: Impacts of sea level rise towards 2100 on buildings in Norway, Build. Res. Inf., 40, 245259, https://doi.org/10.1080/09613218.2012.690953, 2012.

Aunan, K. and Romstad, B.: Strong coasts and vulnerable communities: Potential implications of accelerated sea-level rise for Norway, J. Coast. Res., 24, 403-409, https://doi.org/10.2112/07A-0013.1, 2008.

Bamber, J. L., Westaway, R. M., Marzeion, B., and Wouters, B.: The land ice contribution to sea level during the satellite era, Environ. Res. Lett., 13, 063008, https://doi.org/10.1088/17489326/aac2f0, 2018.

Breili, K., Simpson, M. J. R., and Nilsen, J. E. Ø.: Observed SeaLevel Changes along the Norwegian Coast, J. Mar. Sci. Eng., 5, 29, https://doi.org/10.3390/jmse5030029, 2017.

Church, J. A., Clark, P. U., Cazenave, A., Gregory, J. M., Jevrejeva, S., Levermann, A., Merrifield, M. A., Milne, G. A., Nerem, R. S., Nunn, P. D., Payne, A. J., Pfeffer, W. T., Stammer, D., and Unnikrishnan, A. S.: Sea level change, in: Climate Change 2013: The Physical Science Basis, Contribution of Working Group I to the Fifth Assessment Report of the Intergovernmental Panel on Climate Change, chap. 13, edited by: Stocker, T. F., Qin, D., Plattner, G. K., Tignor, M., Allen, S. K., Boschung, J., Nauels, A., Xia, Y., Bex, V., and Midgley, P. M., Cambridge University Press, ISBN 978-1-107-05799-1, 1137-1216, 2013.

Clark, P. U., Shakun, J. D., Marcott, S. A., Mix, A. C., Eby, M., Kulp, S., Levermann, A., Milne, G. A., Pfister, P. L., Santer, B. D., Schrag, D. P., Solomon, S., Stocker, T. F., Strauss, B. H., Weaver, A. J., Winkelmann, R., Archer, D., Bard, E., Goldner, A., Lambeck, K., Pierrehumbert, R. T., and Plattner, G. K.: Consequences of twenty-first-century policy for multi-millennial climate and sea-level change, Nat. Clim. Change, 6, 360-369, https://doi.org/10.1038/NCLIMATE2923, 2016.

Cooper, H. M. and Chen, Q.: Incorporating uncertainty of future sea-level rise estimates into vulnerability assessment: a case study in Kahului, Maui, Climatic Change, 121, 635-647, https://doi.org/10.1007/s10584-013-0987-x, 2013. 
Cooper, H. M., Fletcher, C. H., Chen, Q., and Barbee, M. M.: Sea-level rise vulnerability mapping for adaptation decisions using LiDAR DEMs, Prog. Phys. Geogr., 37, 745-766, https://doi.org/10.1177/0309133313496835, 2013.

DeConto, R. M. and Pollard, D.: Contribution of Antarctica to past and future sea-level rise, Nature, 531, 591-597, https://doi.org/10.1038/nature17145, 2016.

Edwards, T. L., Brandon, M. A., Durand, G., Edwards, N. R., Golledge, N. R., Holden, P. B., Nias, I. J., Payne, A. J., Ritz, C., and Wernecke, A.: Revisiting Antarctic ice loss due to marine ice-cliff instability, Nature, 566, 58-64, https://doi.org/10.1038/s41586-019-0901-4, 2019.

Geonorge: Shared map catalogue of Norway, Web portal, available at: https://www.geonorge.no/en (last access: 24 February 2020), 2019.

Gesch, D. B.: Analysis of Lidar Elevation Data for Improved Identification and Delineation of Lands Vulnerable to Sea-Level Rise, J. Coast. Res., 53, 49-58, https://doi.org/10.2112/SI53-006.1, 2009.

Gesch, D. B.: Consideration of Vertical Uncertainty in ElevationBased Sea-Level Rise Assessments: Mobile Bay, Alabama Case Study, J. Coast. Res., 63, 197-210, https://doi.org/10.2112/SI63016.1, 2013.

Gesch, D. B.: Best Practice for Elevation-Based Assessment of SeaLevel Rise and Coastal Flooding Exposure, Front. Earth. Sci., 6, 230, https://doi.org/10.3389/feart.2018.00230, 2018.

IPCC: Summary for Policymakers, in: Climate Change 2013: The Physical Science Basis, Contribution of Working Group I to the Fifth Assessment Report of the Intergovernmental Panel on Climate Change, edited by: Stocker, T. F., Qin, D., Plattner, G. K., Tignor, M., Allen, S. K., Boschung, J., Nauels, A., Xia, Y., Bex, V., and Midgley, P. M., Cambridge University Press, ISBN 9781-107-05799-1, 2013.

Kartverket: Forprosjekt "Nasjonal, detaljert høydemodell", Tech. rep., Norwegian Mapping Authority, available at: https://hoydedata.no/LaserInnsyn/ (last access: 24 February 2020), 2014.

Kartverket: The Norwegian coastline, Web portal, available at: https://www.kartverket.no/kunnskap/Fakta-om-Norge/ norges-kystlinje/kystlinjen-i-kilometer (last access: 24 February 2020), 2019a.

Kartverket: The SOSI-standard, Web portal, available at: https://www.kartverket.no/geodataarbeid/Standarder/SOSI/ SOSI-standarden-del-2 (last access: 24 February 2020), 2019 b.

Kartverket: Se havnivå i kart (View sea-level rise in maps), Web portal, available at: https://www.kartverket.no/en/sehavniva (last access: 24 February 2020), 2019c.

Kierulf, H. P., Steffen, H., Simpson, M. J. R., Lidberg, M., Wu, P., and Wang, H.: A GPS velocity field for Fennoscandia and a consistent comparison to glacial isostatic adjustment models, J. Geophys. Res.-Solid, 119, 6613-6629, https://doi.org/10.1002/2013JB010889, 2014.

Le Cozannet, G., Nicholls, R. J., Hinkel, J., Sweet, W. V., McInnes, K. L., Van de Wal, R. S. W., Slangen, A. B. A., Lowe, J. A., and White, K. D.: Sea Level Change and Coastal Climate Services: The Way Forward, J. Mar. Sci. Eng., 5, 49, https://doi.org/10.3390/jmse5040049, 2017.

$\mathrm{Li}, \mathrm{Z}$.: Variation of the accuracy of digital terrain models with sampling interval, Photogramm. Rec., 14, 113-128, 1992.
Næss, A. and Gaidai, O.: Estimation of extreme values from sampled time series, Struct. Saf., 31, 325-334, https://doi.org/10.1016/j.strusafe.2008.06.021, 2009.

Nicholls, R. J.: Impacts of and Responses to Sea-Level Rise, in: Understanding Sea-Level Rise and Variability, edited by: Church, J. A., Woodworth, P. L., Aarup, T., and Wilson, W. S., WileyBlackwell, ISBN 978-1-4443-3452-4, 17-51, 2010.

Nicholls, R. J. and Cazenave, A.: Sea-Level Rise and Its Impact on Coastal Zones, Science, 328, 1517-1520, https://doi.org/10.1126/science.1185782, 2010.

Olesen, O., Kierulf, H. P., Brönner, M., Dalsegg, E., Fredin, O., and Solbakk, T.: Deep weathering, neotectonics and strandflat formation in Nordland, northern Norway, Nor. J. Geol., 93, 189213, 2013.

Ouassou, M., Jensen, A. B. O., Gjevestad, J. G. O., and Kristiansen, O.: Next Generation Network Real-Time Kinematic Interpolation Segment to Improve the User Accuracy, Int. J. Navigat. Obs., 2015, 346498, https://doi.org/10.1155/2015/346498, 2015.

Passeri, D. L., Hagen, S. C., Medeiros, S. C., Bilskie, M. V., Alizad, K., and Wang, D.: The dynamic effects of sea level rise on lowgradient coastal landscapes: A review, Earth's Future, 3, 159181, https://doi.org/10.1002/2015EF000298, 2015.

Poulter, B. and Halpin, P. N.: Raster modelling of coastal flooding from sea-level rise, Int. J. Geogr. Inf. Sci., 22, 167-182, https://doi.org/10.1080/13658810701371858, 2008.

Reutebuch, S. E., McGaughey, R. J., Andersen, H. E., and Carson, W. W.: Accuracy of a high-resolution lidar terrain model under a conifer forest canopy, Can. J. Remote. Sens., 29, 527-535, https://doi.org/10.5589/m03-022, 2003.

Roelvink, D., Reniers, A., Van Dongeren, A., van Thiel de Vries, J., McCall, R., and Lescinski, J.: Modelling storm impacts on beaches, dunes and barrier islands, Coast. Eng., 56, 1133-1152, https://doi.org/10.1016/j.coastaleng.2009.08.006, 2009.

Rowley, R. J., Kostelnick, J. C., Braaten, D., Li, X., and Meisel, J.: Risk of rising sea level to population and land area, Eos Trans. Am. Geophys. Union, 88, 105-107, 2007.

Sibson, R.: A brief description of natural neighbor interpolation, in: Interpreting Multivariate Data, chap. 2, edited by: Barnett, V., John Wiley, New York, ISBN 978-047128039, 21-36, 1981.

Simpson, M. J. R., Nilsen, J. E. Ø., Randal, O. R., Breili, K., Sande, H., Kierulf, H. P., Steffen, H., Jansen, E., Carson, M., and Vestøl, O.: Sea Level Change for Norway: Past and Present Observations and Projections to 2100, report 1/2015. Norwegian Centre for Climate Services, Oslo, Norway, ISSN 2387-3027, Tech. rep., 2015.

Simpson, M. J. R., Ravndal, O. R., Sande, H., Nilsen, J. E. Ø., Kierulf, H. P., Vestøl, O., and Steffen, H.: Projected 21 st century sea-level changes, extreme sea levels, and sea level allowances for Norway, J. Mar. Sci. Eng., 5, 36, https://doi.org/10.3390/jmse5030036, 2017.

Skjong, M., Naess, A., and Brandrud Næss, O. E.: Statistics of Extreme Sea Levels for Locations along the Norwegian Coast, J. Coast. Res., 29, 1029-1048, https://doi.org/10.2112/JCOASTRES-D-12-00208.1, 2013.

Solheim, D.: New height reference surfaces for Norway, in: Report on the Symposium of the IAG Subcommission for Europe (EUREF) in Troms $\varnothing$, edited by: Torres, J. A. and Hornik, H., Verlag der Bayer. Akad. der Wiss., Munich, Germany, 154-158, 2000. 
SSB: Statistics Norway: Land use and land cover, Web portal, available at: https://www.ssb.no/en/natur-og-miljo/statistikker/ arealstat (last access: 24 February 2020), 2019.

Strauss, B. H., Ziemlinski, R., Weiss, J. L., and Overpeck, J. T.: Tidally adjusted estimates of topographic vulnerability to sea level rise and flooding for the contiguous United States, Environ. Res. Lett., 7, 014033, https://doi.org/10.1088/17489326/7/1/014033, 2012.

Strauss, B. H., Kulp, S., and Levermann, A.: Carbon choices determine US cities committed to futures below sea level, P. Natl. Acad. Sci. USA, 112, 13508-13513, https://doi.org/10.1073/pnas.1511186112, 2015.

Taylor, K., Stouer, R. J., and Meehl, G. A.: An overview of CMIP5 and the experiment design, B. Am. Meteorol. Soc., 93, 485-498, https://doi.org/10.1175/BAMS-D-11-00094.1, 2012.

TEK: Buildings acts for Norway (TEK17) [technical manual], Web portal, available at: https://dibk.no/byggereglene/ byggteknisk-forskrift-tek17 (last access: 24 February 2020), 2019.
Titus, J. G. and Narayanan, V. K.: The Probability of Sea Level Rise, Tech. rep., US Environmental Protection Agency, Washington, D.C., USA; Office of Policy, Planning, and Evaluation, Bethesda, MD, USA; Climate Change Division, Adaptation Branch, Washington, D.C., USA, 1995.

UNESCO: UNESCO World Heritage Center, World Heritage List, available at: http://whc.unesco.org/en/list (last access: 24 February 2020), 2019.

Vestøl, O.: Determination of postglacial land uplift in Fennoscandia from leveling, tide-gauges and continuous GPS stations using least squares collocation, J. Geod., 80, 248-258, https://doi.org/10.1007/s00190-006-0063-7, 2006.

Vousdoukas, M. I., Mentaschi, L., Voukouvalas, E., Bianchi, A., Dottori, F., and Feyen, L.: Climatic and socioeconomic controls of future coastal flood risk in Europe, Nat. Clim. Change, 8, 776780, https://doi.org/10.1038/s41558-018-0260-4, 2018a.

Vousdoukas, M. I., Mentaschi, L., Voukouvalas, E., Verlaan, M., Jevrejeva, S., Jackson, L. P., and Feyen, L.: Global probabilistic projections of extreme sea levels show intensification of coastal flood hazard, Nat. Commun., 9, 2360, https://doi.org/10.1038/s41467-018-04692-w, 2018b. 